\title{
Do Directives Always Direct? Cognitive Directives and Meaning Inculcation in El-Sisi's Improvised Speeches:
}

A Pragma-Semantic Analysis

Ayman F. Khafaga

(Faculty of Arts, Suez Canal University)

\section{Abstract}

This paper investigates three types of directives used in President El-Sisi's improvised speeches: directive questions, directive commands, and directive modality. The main objective of this paper is to test the hypothesis that directives, irrespective of their type, do not necessarily seek information (as is the case for questions), require a verbal/physical response (as is the case for commands), or prospect an obligation (as is the case for obligation modality). More specifically, this paper tries to show how certain presidential meanings are linguistically inculcated by a particular directive mood through which a cognitive activity is initiated on the part of the interlocutors towards the acceptance of certain arguments in a particular way. The two research questions in this paper are: first, what are the presidential meanings El-Sisi wants to inculcate in his addressees? Second, what is the effect of using directives in presidential speeches' context in relation to the exercise of meaning inculcation? This paper draws upon two analytical approaches: Speech acts theory instanced by directives (Austin, 1962; Searle, 1969, 1976) and Ervin-Tripp's (1976) classification of directives. Two main findings are shown in this paper: first, El-Sisi uses directive questions, directive commands and directive modality to influence his addressees' attitudes rather than to prospect and/or stimulate their verbal/physical performance. Second, directives are employed in the speech to initiate a cognitive link that operates as a communicative channel through which specific presidential meanings are intended to be inculcated.

العدد الخامس والعشرون (الجزء الثانى)

()

مجلة كلية التربية- جامعة عين شمس115 
Do Directives Always Direct? Cognitive Directives and Meaning Inculcation in El-Sisi's Improvised Speeches

Keywords: directive questions; directive commands; directive modality; meaning inculcation; pragma-semantic analysis; El-Sisi's improvised speeches 


\section{Do Directives Always Direct? Cognitive Directives and Meaning Inculcation in El-Sisi's Improvised Speeches:}

A Pragma-Semantic Analysis

Ayman F. Khafaga

(Faculty of Arts, Suez Canal University)

\section{Introduction}

Discourse has many classifications that characterize its different modes of production. One division is between "spontaneous and manufactured varieties" (Clark, 2014, p. 292). A manufactured discourse is one that "has been prepared, reworked, and turned into an artifact or performance" (ibid.), whereas spontaneous (improvised) discourse is "created on the fly" (ibid.), is often attached to "natural communication situations" (Brennenstuhl, 1987 , p. 65), and lacks “written normativity” (Sindoni, 2013, p. 28). Abdel Fattah El-Sisi's (1954- ) speeches adopted two modes of delivery: formal mode in which an act of reading represents the medium through which speech is communicated, and informal improvised mode in which ideas are conveyed in a spontaneous manner. The second type of El-Sisi's speeches (i.e. improvised one), the core concern of this paper, is characterized by different types of directives that go beyond their semantic nature of mere directivity towards specific pragmatic purposes that aim to inculcate certain presidential meanings.

This paper investigates three types of directives in one of ElSisi's improvised speeches: directive questions, directive commands and directive modality, by arguing for the assumption that directives are sometimes employed to inculcate meanings rather than merely

العدد الخامس والعشرون (الجزء الثاني) 2019

()

مجلة كلية التربية- جامعة عين شمس117 


\section{Do Directives Always Direct? Cognitive Directives and Meaning}

Inculcation in El-Sisi's Improvised Speeches

direct addressees towards textual and/or physical actions, the normal usage of directives within the framework of speech acts theory (e.g. Austin, 1962; Searle, 1969, 1976, 1979; Grice, 1975). This process of meaning inculcation is basically based on managing the interlocutors' pragmatic competence by influencing their cognitive unit of knowledge (i.e. their schemata) towards specific meanings. This is conducted by contextually framing what is intended to be inculcated in a directive code that is linguistically manifested in the three types of directives under investigation. The core idea of this paper, therefore, is to test the hypothesis that directives are not only employed to make hearers do something, verbal or physical, but also to affect a change in cognitive behavior that allows the reception of certain arguments in a particular way.

This paper uses a pragma-semantic approach to analyze directives in the selected speech. This is because the selected speech abounds in different types of directives characterized by significant pragmatic and semantic features that are worthy of linguistic research, particularly when these directives are analyzed from a linguistic perspective that differs from their generally-perceived one, i.e. their normal use of directing hearers/readers to carry out or to refrain from certain actions. Two theoretical frameworks underpin this study: Speech acts theory instanced by directives (Austin, 1962; Searle, 1969, 1976) and Ervin-Tripp's (1976) classification of directives. Two main research questions are tackled here: first, what are the presidential meanings El-Sisi wants to inculcate in his addressees? Second, what is the effect of using directives in presidential speeches' context in relation to the exercise of meaning inculcation? By using a pragma-semantic approach and by answering the two research questions, this paper tries to explore how specific presidential meanings are inculcated by making a

العدد الخامس والعشرون (الجزء الثانى)

مجلة كلية التربية- جامعة عين شمس118 
connection between propositional contents of surface linguistic expressions represented in a directive code (semantic) and new meanings derived from a cognitive inferential activity (pragmatic).

The paper is organized as follows. Section 2 presents a theoretical background and a theoretical framework to the meaning of directives in light of speech acts theory (Austin, 1962; Searle 1969, 1976, 1979) and Ervin-Tripp's (1976) model of directives (1976). The theoretical framework applied to the analysis of data is mainly based on and selectively derived from the two analytical strands adopted in this paper. This section also reviews some previous studies relevant to the topic under investigation. Section 3 discusses the methodology of the study, focusing on the nature of the selected data and the analytical procedures implemented. Section 4 is confined to data analysis. Section 5 discusses the findings of the study. The paper ends in Section 6, which offers the conclusion and some remaining questions with further directions for future research.

\section{Theoretical background and framework \\ 2.1. Speech acts theory: A brief account}

Speech acts theory was introduced to linguistics by Austin (1962) and developed by Searle (1969, 1979) and Grice (1975). This theory is central to pragmatics, particularly when we come to the interpretation of meanings carried out by words in different contextual situations. Different taxonomies have been ascribed to speech acts. Concerning the actions performed, speech acts, for Austin (1962), are divided into locutionary, illocutionary and perlocutionary. Locutionary acts refer to the act of saying the utterance, that is, the grammatical way an utterance constitutes. Locutionary acts can be expressed declaratively, interrogatively, imperatively or exclamatory. Illocutionary acts basically depend on the intention of the speaker. This intended meaning is called illocutionary force, and sometimes needs an understanding of the context in which the utterance is used to be grasped. Perlocutionary acts refer to the effect the utterance has on the hearers, either

$$
2019 \text { العدد الخامس والعشرون (الجزء الثالن) }
$$

مجلة كلية التربية- جامعة عين شمس 119 


\section{Do Directives Always Direct? Cognitive Directives and Meaning}

Inculcation in El-Sisi's Improvised Speeches

intentionally or unintentionally. With regard to the discourse function, speech acts are categorized into assertive, directives, expressives, commissives, and declaratives (Searle, 1979). As for the structure-function relationship, speech acts are classified into direct, in which the relationship between the structure of utterances and the communicative functions they convey is direct; and indirect, in which the relationship between form and function is indirect (Yule, 1996).

For Searle (1979), a speech act consists of two main elements: the first is the propositional content, which is based on truthconditions; and the second is illocutionary force, which is speaker's intention-oriented. Thus, performing a speech act, for him (ibid.) means to express a propositional content associated with an illocutionary force. He proceeds that the speaker's intention and the ability of the hearer's to recognize it are necessary for a speech act to be realized. Searle then casts special emphasis on the cognitive dimension of speech acts (intentions). Here lies the relevance of directive speech acts to the study of meaning inculcation since both of them are not only concerned with conventional aspects of utterances production, but the intentional one as well. This intentional perspective of speech acts makes Grice (1975) differentiate between natural meaning and non-natural meaning. For him (ibid.), the former deals with the surface meaning a speech act expresses and the latter focuses on the implied intentional one.

Following Searle's intentional dimension of speech acts, Sperber and Wilson's (1995) relevance theory leaves a space for mind in order to infer further meanings (pragmatic) pertaining to speech acts other than what is simply encoded in the surface linguistic expressions (semantic). Thus, it is not only the meaning recognition of an utterance that judges the success of a speech act, but rather the hearer's inference of the speaker's intended meaning. For them (ibid.), one can get the informative intention (i.e. the intended meaning) of the speaker if he manages to infer new
2019
العدد الخامس والعشرون (الجزء الثان)
()
مجلة كلية التربية- جامعة عين شمس 120 
information relevant to the utterance and different from the old information he stores in mind (his schemata). The focus then is not only on physical and/or textual acts that are done by speech acts, but rather on communicative intentions that emphasize the cognitive dimension of language contents.

\subsubsection{Directives}

Directives, being one type of speech acts (Searle, 1979) as well as a speech function (Jakobson, 1997), are extensively discussed by many linguists (Austin, 1962; Searle, 1969, 1976, 1979; Grice, 1975; Sinclair\& Coulthard, 2002; Leech, 2014; Povolná, 2018), among others. These studies have agreed to one meaning of directives; that is, they are a type of speech acts in which speakers attempt to make their hearers carry out or to refrain from certain actions. Thus, directives require two processes: intentional attempts from speakers to initiate particular actions and verbal/physical (sometimes cognitive) commitment on the part of the hearers to carry out specific actions. The concept of intentionality, on the one hand, is clearly stated by Crystal (1992, p. 362) who perceives directives to be communicative activities that depend on two elements: "the intention of a speaker while speaking" and "the effects achieved on a listener." The notion of commitment, on the other hand, is derived from the forcefulness practiced on hearers by a directive code, which is also emphasized by Ryckebusch and Marcos (2004, p. 884), who state that directives "aim at getting one's partner to do something." Further, intentionality and commitment are significant elements in the process of inculcation because the latter can only be realized through a communication activity which, for Dascal (2003), is often governed by the desire of the speaker to be understood, that is, to guarantee the absorption of his intended meanings (intentionality), and the responsibility of the hearer to understand, that is, to better perceive the unsaid (commitment).

For Searle (1976, p. 11), the commitment for a future action is always an inherited element of directives since they, for him, always
2019
العدد الخامس والعشرون (الجزء الثانى)
()
مجلة كلية التربية- جامعة عين ثمس121 


\section{Do Directives Always Direct? Cognitive Directives and Meaning}

\section{Inculcation in EI-Sisi's Improvised Speeches}

require "some future action," which, for Povolná (2018, p.75), has three linguistic manifestations: (i) the use of imperatives of the full verbs; (ii) the presence of modal verbs of obligation, necessity or prohibition addressed to the reader; and (iii) the presence of predicative adjectives expressing the writer's judgment of the necessity to perform an action. Sinclair and Coulthard (2002) argue that directives are most likely occur in the different forms of spoken discourse, and are grammatically realized by imperatives and sometimes by interrogatives. They proceed that directives are usually accompanied by "boundary exchanges" (ibid., p. 25) that constitute two stages: "framing" and "focusing" (ibid., p. 25). The two boundary stages, for them, occur together in spoken discourse. 'Framing' marks the beginning of a new piece of information within discourse, and 'focusing' reflects what this piece of information is about. In this paper, three types of directives are discussed: directive questions, directive commands, and directive modality. These will theoretically be reviewed in the subsections below.

\subsubsection{Directive questions}

The literature on directive questions shows that they have been tackled from different linguistic dimensions; pragmatically, as referring to illocutionary acts (Lyons, 1977, 1981; Huddleston, 1984); semantically, as an information-seeker category (Quirk, Greenbaum, Leech, \& Svartvik, 1985); and a third party characterizes questions as tools for initiating directives (Gordon \& Lakoff, 1975). According to Tsui (2002), questions are marked by their interrogative form and sometimes by the discourse function they initiate on the part of the addressees. Questions, in this sense, are "sometimes taken as a syntactic category and sometimes a discourse category" (ibid., p. 89). This categorization dimensionality of questions asserts their linguistic flexibility to permit different uses for various purposes. Among these uses is that one which is based on the illocutionary force of questions which, for Lyons (1977), characterizes them from other syntactic forms such as

العدد الخامس والعشرون (الجزء الثالن) 2019

()

مجلة كلية التربية- جامعة عين شمس122 
statements, and casts light on their pragmatic dimension as well as their function in discourse.

According to Benz and Jasinskaja (2017), there is a close relationship between questions and their answers in discourse in the sense that questions, for them, are linguistically perceived as "templates for possible answers," which contribute to the semantics of questions in discourse. They (ibid.) relate the understanding of the meanings of questions to the recipients' ability to grasp the speakers' intended goals. Thus, they cast emphasis on the cognitive ability of readers to perceive the implied meanings of questions. They, therefore, see questions "as a conceptualization for discourse goals of the speakers that stand in a systematic relation to their domain-level goals" (ibid., p. 178).

Semantically, questions, for Quirk et al. (cited in Tsui, 2002, p. 89 ), are used in discourse "to seek information on a specific point." For them (ibid.), questions encompass three types. First, "YES/NO questions" which "expect affirmation or negation." Second, "WHquestions" which "expect a reply from an open range of replies." Third, "ALTERNATIVE questions" which "expect as the reply one of two or more options presented in the question" (p. 89, capitals in original). Unlike confirmation-seeking questions (i.e. yes/no questions), wh- questions are information-seeking type that "are realized by wh- words," "usually spoken with falling intonation," and "the answer expected is the missing piece of information denoted by the wh-word" (Tsui, 2002, p. 94). Additionally, Sudo (2007) sees that questions do not carry meanings by their constituent parts (i.e. syntactic forms), their meanings, however, are closely associated with their answers. Thus, subsequent utterances add to the semantics of questions, lessen their directive force, and

2019 العدد الخامس والعشرون (الجزء الثان)

مجلة كلية التربية- جامعة عين ثمس123 
Do Directives Always Direct? Cognitive Directives and Meaning Inculcation in El-Sisi's Improvised Speeches

support their cognitive inculcation perspective communicated by the propositional contents encoded in these subsequent answers.

\subsubsection{Directive commands}

Directive commands are linguistically realized by imperatives. So, one should reflect on imperatives in order to understand how they are used to issue commands. Imperatives have been analyzed from different theoretical perspectives: syntactically, by focusing on their structural and grammatical forms (Thorne, 1966; Han, 2000); from a relevance-theoretic perspective (Wilson \& Sperber, 1988; Clark, 1993); and in terms of their pragmatic dimension, by highlighting their illocutionary force (Sadock, 1974; Downes, 1977).

Davies (1986, p. 72) argues that "the utterance of an imperative is understood as an expression of acceptance of the proposition's being made true." She also points out that when speakers use imperatives, they are "always understood to be putting forward the idea of the addressees realizing the possibility presented" (ibid., p. 145). For Leech (1983, p. 119), imperatives "present the propositional content as a candidate for fulfilment by hearers." The act of actions implementation on the part of the addressees asserts the sense of commitment the speaker creates when using commands, and emphasizes the assumption that imperatives create "an obligation" (Condoravdi \& Lauer, 2012, p. 37) on the part of the addressees. Crucially, this commitment is not only confined to linguistic activities, i.e. verbal performances, but also, in some cases, a cognitive commitment towards specific ideas is targeted. This cognitive directivity is the sole aim of directive commands discussed in this paper. They are not "action-inducing" (ibid., p. 41), but cognitive commitment-motivating; that is, a commitment which

2019 العدد الخامس والعشرون (الجزء الثان)

()

مجلة كلية التربية- جامعة عين شمس124 
does not require addressees to make "the right action choices" (ibid., p. 46), but rather to influence a change in their attitudes.

According to Portner (2007), imperatives have directive meaning used to get someone to take non-linguistic action. This concept of directivity is emphasized by Kent and Kendrick (2016, p. 272) who list "directing" among the wide range of actions performed by means of imperatives, and has previously been supported by Zanuttini and Portner's (2003) argument that directivity in imperatives is the basis upon which one can differentiate between the other types of clauses, namely the declarative and the interrogative. This directive force is supported by Condoravdi and Lauer (2012) who state that imperatives are perceived as directives that are linguistically manifested in orders, warnings, and requests. Thus, since imperatives are used to "convey directive force," it is normally perceived that "command is often taken to be the basic function of the imperative verb" (von Fintel \& Iatridou, 2017, p. 288).

\subsubsection{Directive modality}

Research on modality offers various taxonomies to the term, ranging from the meaning of the mere individual modal expressions to the contextual factors constituting their overall production and meaning in discourse. Some discuss modality from a semantic perspective (Lyons, 1977, 1983; Palmer, 1986), arguing that modality has two types: epistemic and deontic. The former refers to the semantic meanings of necessity, possibility and/or prediction, and the latter comprises the domains of obligation, permission, and/or volition. This group of studies focuses on the role of speakers in the process of interaction. This role, for Lyons (1983, p. 111) is called "subjectivity" which means "the locutionary agent's (speaker) involvement of himself in the utterance" (ibid., p. 111).

García (2000, p. 127-128) further argues that there are two meanings pertaining to modality: "a systematic meaning" and "a pragmatic meaning" which, for him, capture "the relationship

2019 العدد الخامس والعشرون (الجزء الثان)

()

مجلة كلية الزبية- جامعة عين شمس125 


\section{Do Directives Always Direct? Cognitive Directives and Meaning}

\section{Inculcation in El-Sisi's Improvised Speeches}

between the locutionary resources of modality and the interpersonal function it can perform in the process of negotiation in a dynamic, comprehensive way." The systematic meaning, on the one hand, according to García (ibid.), refers to the general meaning presented by the different uses of a modal accompanied with the contextual meanings a modal acquires from discourse environment. The pragmatic meaning, on the other hand, focuses on the meanings the interlocutors gain from both linguistic and nonlinguistic elements of the text, i.e. the context of utterance.

According to Walton (1991), modalities, though they have a general meaning which is semantically-based, they always need a contextual framework that extends and allows more meanings to their semantic and pragmatic nature. This contextually-based view of modality, for von Fintel (2006, p. 23), means that modals have "a rather skeletal meaning and it is only in combination with the background context that they take on a particular shade of meaning." Significantly, this variegation of meanings pertaining to modalities validates their diversely classificatory nature, which in turn allows the introduction of new dimensions to them, particularly the cognitive.

\subsection{Ervin-Tripp's model of directives}

Ervin-Tripp (1976) classifies directives into six types that constitute the different linguistic manifestations of the term in spoken discourse. She asserts that her classification is based on and ordered according to "the relative power of speaker and addressee in conventional usage and the obviousness of the directive" (ibid., p. 29). The six types of directives for her are: "Need statements, imperatives, imbedded imperatives, permission directives, question directives, and hints" (ibid., p. 29, italics in original). In terms of Ervin-Tripp's 'need statements', she argues that they "occurred between persons differing in rank," maintaining that a statement of need, once delivered from a superior speaker, implies "an obligation on the part of the subordinate" (ibid., p. 29). She states that in "need

العدد الخامس والعشرون (الجزء الثالن) 2019

مجلة كلية التربية- جامعة عين شمس126 
statements', the needed thing is bluntly expressed by the speaker as is the case in using imperatives.

The second type of Ervin-Tripp's (1976) directives is the 'imperatives'. She argues that they "normally include a verb and, if it is transitive, an object, and sometimes a beneficiary" (p. 30). She emphasizes that when imperatives include certain expressions that are used as "preposed greetings, attention-getters like 'hey' or 'excuse me', names or honorific address terms, and 'please'," they function then to call "attention to a gesture or to what will follow" (ibid., p. 31). For her, the use of the mitigating marker 'please' "signals that a directive will follow" (ibid., p. 31).

Proceeding with her model, Ervin-Tripp (1976, p. 33) argues that 'imbedded imperatives' are used for "all instances in which agent and object are explicit, so that the forms preceding them are a kind of formal addition" as in her example: "Would you mind opening the window?" (ibid., p. 33, italics in original). Ervin-Tripp (ibid.) maintains that despite their interrogative forms, there is no interpretative problem concerning the meanings of imbedded imperative in the above example as it carries the meaning of the imperative 'open the window'. The fourth type of directives is 'permission directives' which consist of "modal+beneficiary+have/verb+?" (ibid., p. 37). Ervin-Tripp lists three modal verbs that are used in this type of directives. These are "can, could, and their negatives, and may" (ibid., p. 37, italics in original). As for 'question directives', they "give the listener who does not want to comply an escape route, in treating the question directive as if it were an information question" (ibid., p. 38). The sixth, and last, type of directives is 'hints'. Ervin-Tripp points out that hints communicate various functions, require "shared knowledge" between speakers and hearers, and "serve solidarityenhancement" (ibid., p. 43).

\subsection{Directives and cognitive meaning construction}

In searching for how cognitive meaning is constructed through speech acts, Baicchi (2015), inspired by Reddy's (1979) conduit

العدد الخامس والعشرون (الجزء الثانى) 2019

مجلة كلية التربية- جامعة عين شمس127 


\section{Do Directives Always Direct? Cognitive Directives and Meaning}

\section{Inculcation in EI-Sisi's Improvised Speeches}

metaphor model, postulates that cognitive meaning is formed through four phases that constitute the three elements in interpersonal communication: the speaker, the hearer and the utterance. The first phase represents the ideas and thoughts a speaker has in mind before producing the utterance ('objects' in Reddy's (1979) terms); the second phase comprises the words and sentences selected to carry these ideas and thoughts and thus convey the speaker's communicative intention ('containers' in Reddy's (1979) terms); the third phase encompasses the linguistic code within which ideas are framed to be sent to hearers ('conduit' in Reddy's (1979) terms); and the fourth phase involves hearers to receive these utterances and "to unpack the utterance-container in order to identify the speaker's communicative intention" (Baicchi, 2015, p. 107).

Baicchi's three phases of cognitive meaning construction correlate with Fairclough's (2003) argument that meaning-making is a process which involves "the production of the text, the text itself, and the reception of the text" (p. 10), with a focus on the intention of the speaker in the text production stage and the interpretative ability of hearers to understand the communicative purposes of the speakers in the reception stage. For him, meaning-making is based on both the explicit expressions of utterances and the implicit meaning assumed by hearers. Thus, to construct meaning in discourse, a tripartite relationship is required between the said (semantic), the unsaid (pragmatic) and the hearer's ability to go beyond the said towards the unsaid to infer meaning (cognitive).

Thornburg and Panther (1997) link the meaning pertaining to speech acts to the principles of Cognitive Linguistics and argue that cognitive meaning of directive speech acts is constructed by what they term "illocutionary scenarios" (p. 207). These scenarios, for them, comprise three main elements: "BEFORE," "CORE" and "AFTER" (ibid., p. 207, capitals in original). These three components, for Baicchi (2015, pp. 107-108), correspond to
2019
العدد الخامس والعشرون (الجزء الثاني)
()
مجلة كلية التربية- جامعة عين شمس128 
"pragmatic preconditions," "pragmatic core and result" and "pragmatic consequences," respectively. The first element refers to the ability to carry out and motivate a specific response; the second component represents the performance of the speech act itself; and the third constitutes the intended consequences of the speech act. Thornburg and Panther (ibid.) maintain that these scenarios are preconditions for the successful of the speech acts performance, and the activation of one element is enough to activate the rest of directive scenarios in the hearer's mind.

Proceeding with their illocutionary scenarios, Thornburg and Panther (1997) argue that the 'before' stage contains "a mental attitude of the speaker" (p. 208), in which the speaker desires that the action is to be implemented by the hearer. This stage, for Thornburg and Panther, is regarded as "motivation or reason for carrying out both the speech act and the associated non-linguistic action" (ibid., p. 208). The "core' stage is also called "essential condition" or "illocutionary point" (ibid., p. 208) and refers to the assumption that the hearer is under a strong obligation to carry out the action, particularly if the speaker's intention beyond the directive speech act is successfully communicated. The 'after' stage focuses on the realization of the propositional content of the directive speech act. Thornburg and Panther (1997) conclude that recognizing the intended meaning beyond a speech act requires some sort of inference on the part of the hearer which is mainly based on what is literally communicated, or as they put it, "the linguistic and extralinguistic context of the utterance" (p. 217).

Based on the idea that intentionality is one essential element that characterizes the illocutionary force of directive speech acts (Searle, 1979), and given the assumption that recognizing such an illocutionary force (i.e. speaker's intention), particularly if these directives go beyond their semantic meanings (natural meanings in the Gricean sense) towards pragmatic ones (the non-natural meaning in the Gricean sense), is a precondition for the realization of a speech act (Grice, 1975), together with the hearer's inferences

العدد الخامس والعشرون (الجزء الثانى) 


\section{Do Directives Always Direct? Cognitive Directives and Meaning}

Inculcation in EI-Sisi's Improvised Speeches

of the speaker's communicative intention (Martinez, 2011), which is cognitive-relevance in nature (Sperber \& Wilson, 1995), it follows then that the understanding of the intended meaning beyond the mere linguistic expressions of directives is systematically constructed within a cognitive framework. In light of this paper, this framework of cognitive meaning construction consists of directive utterances (locution/semantic), an intentional message inculcation (illocution/ pragmatic), and a targeted change in behavior (perlocution/ cognitive).

\subsection{Previous studies}

Previous studies show that directives have been approached from different perspectives, within and beyond the scope of political discourse. For example, pragmatically, directives are discussed with respect to a variety of concepts, such as politeness (Blum-Kulka, 1987), turn-taking sequences (Goldschmidt, 1998), power relations (Blum-Kulka, 1990), and the relationship between gender and power (Vine, 2004); within workplace discourse, directives are studied to highlight the extent to which gendered language, politeness strategies and professional identities are reflected by means of a particular directive mood (Saito \& Cook, 2018); and in classroom interactions, directives are investigated to show how different pronouns are employed in directive forms within the oral discourse of college laboratory sessions (Tapper, 1994) and the different directive sequences employed in faculty meeting at Japanese secondary schools (Naomi, 2018).

Within the scope of political discourse, a considerable number of studies discussed directives as one among other types of speech acts, and within the framework of speech acts theory. For example, investigating negative politeness strategies in directive speech acts employed in parliamentary debates (Dontcheva-Navratilova, 2005); discussing the role of directive speech acts in the public service advertisements directed to voters before elections (Mbisike, 2008);

العدد الخامس والعشرون (الجزء الثانى)

مجلة كلية التربية- جامعة عين شمس 130 
and analyzing speech acts in political speeches of political leaders (Sheveleva, 2012; Safwat, 2015; Dylgjeri, 2017), among others.

As for the political speeches of El-Sisi, they are investigated from different standpoints; by adopting a rhetorical and linguistic approach that is mainly based on the theory of persuasion to highlight the different persuasive strategies employed in the speech, such as the use of contrastive pairs, religious citations and specific grammatical structures (Abdel-Moety, 2015); by using critical discourse analysis to show how certain linguistic devices, including figures of speech, collocation and repetition are employed to communicate particular ideologies ( Hussein, 2016); by analyzing the semiotics of the sign system in two posters of El-Sisi during his presidential campaign in 2014, aiming at uncovering the most dominant semiotic features in the selected data, such as presenting El-Sisi as the true representative of Egypt, who has a strong, confident and revolutionary personality (El-Nawawy \& Elmasry, 2016); and by holding a linguistic comparison between two inaugural speeches by two Egyptian presidents: El-Sisi and the former president El-Sadat, with a focus on the different speech acts used by both presidents, particularly commissives and assertives (Sameer, 2017).

The only relevant study which highlights the cognitive dimension of directives is Hyland's (2002), in which he clarifies how directives are used within academic writing framework to guide readers to one specific type of reading (interpretation of texts). Hyland points out that writers use directives to argue for their positions by displaying a command for their material. Within the context of his study, Hyland defines directives as "utterances which instruct the reader to perform an action or to see things in a way determined by the writer" (p. 216). Hyland's definition sheds light not only on the physical/textual dimension of directives, but also their cognitive perspective. Seeing things in a particular way determined by the writer requires a cognitive activity on the part of readers that is based on the illocutionary force of what is literally

العدد الخامس والعشرون (الجزء الثانى) 


\section{Do Directives Always Direct? Cognitive Directives and Meaning}

Inculcation in El-Sisi's Improvised Speeches

expressed in writing. He maintains that directives in academic writing reflect the authority of the writer over his readers to the extent that directs the latter to participate in the text in a specific cognitive way. Hyland's study concludes that directives can guide readers to "certain cognitive acts," where they "are initiated into a new domain of argument, led through a line of reasoning, or directed to understand a point in a certain way" (ibid., p. 218).

\section{Methodology}

\subsection{Data}

The data used for analysis in this paper constitutes one long speech of El-Sisi delivered during his first presidential period. The selected speech was attended to the community representatives on 13th April 2016. It consists of 7996 words, delivered in informal Arabic, and collected from Almenassa Media Center, available at (https://almanassa.com/ar/story/1505).

Three reasons constitute the rationale for the selection of this speech among other improvised speeches of El-Sisi. First, this speech is characterized by an extensive use of directives. Second, it is through such a type of presidential speeches, i.e. improvised speeches, that meanings can linguistically be better inculcated in the addressees. That is because the speech encompasses different linguistic devices that make it discursively relevant to the concept of inculcation; there is a powerful speaker who utilizes various semantic and pragmatic strategies to communicate certain meanings to less powerful addressees. In this regard, Sager, Dungworth, and McDonald (1980) argue that in spoken discourse, the use of directives requires that "the speaker is in some way superior to, in a position to direct, order, or command the listener" (p. 27).Third, the speech can be considered an example that provides a linguistic evidence for Hyland's (2002) and Povolná's (2018) arguments that directives impose a cognitive activity on the addressees.

العدد الخامس والعشرون (الجزء الثانى) 


\subsection{Procedure}

The procedure adopted in this paper incorporates three analytical steps. The first is dedicated to mark the different types of directives presented in the selected speech. These directives are marked only with the intention of addressing three types: questions, commands, and modality. The second is to determine the presidential meanings intended to be inculcated either explicitly or implicitly by a particular directive code. The third is to reflect the extent to which these directives are patterned in a way that reveals the ideological assumptions operating in discourse, which, in turn, functions to activate meaning inculcation in the speech. Additionally, throughout the three analytical procedures, a frequency analysis, which is conducted manually, is offered to provide more linguistic evidences that support the whole analysis of the speech. It is to be noted also that throughout data analysis, the selected extracts will be quoted in their original form of production, i.e. informal Arabic. This will be accompanied by both a colloquial Arabic transliteration (i.e. words are phonetically transcribed in their colloquial manner of production) and an English translation of the original text. The phonetic symbols used in the Arabic transliteration are adopted from International Phonetic Alphabet (IPA) with a few differences. Also, an appendix of the symbols used in this study is attached at the end of this paper.

\section{Analysis}

\subsection{Directive questions in El-Sisi's speech}

Three types of directive questions are used in the speech: whquestions, yes/no questions, and alternative questions. Each type will be discussed in isolation in the subsections below.

\subsubsection{Wh-questions}

The first type of directive questions used in the selected speech is wh-questions. This type is linguistically realized by wh-words, such as what, why, where, and when. Consider the following extracts:

العدد الخامس والعشرون (الجزء الثانى)

مجلة كلية التربية- جامعة عين شمس 133 
Do Directives Always Direct? Cognitive Directives and Meaning Inculcation in EI-Sisi's Improvised Speeches

\section{Extracts 1:}

(يا ترى الدولة المصرية بتسير في أب اتجاه؟.. إحنا فين؟... مكنش فيها رئيس، مكنش

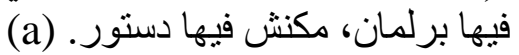

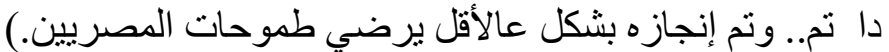
ya tara id-dawlah il-maSriyya betsi:r fi ?ay ?itiga:h ? ?iћna fein ? makanfi fi:ha ra?i:s, makanfi fi:ha barlama:n, makanfi fi:ha dustu:r, ?aw ta3di:la:t id-dustu:r. da tam wi tam ?ingazuh bi-fakl 3ala al?aqal yurDi: Tumu:hā:t il-maSriyyi:n.

"In which direction does the Egyptian state proceed? Where are we now? There was no president, no parliament and no constitution. These things are achieved in a way that, at least, satisfies the ambitions of the Egyptians."

(b) (طب ليه بنعمل كدا؟ بنعمل كدا لجل خاطر بلدنا.)

Tab leih bini3mil kida ? bini3mil kida lagl xā:Tir baladna. "Why do you think we are doing so? We are doing this for the sake of our country."

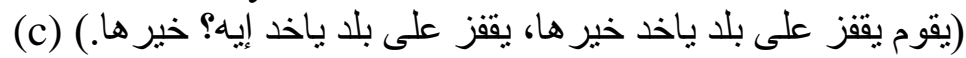

y?u:m yaqfiz 3ala balad yaxud xirha, yaqfiz 3ala balad yaxud ?eih ? xirha.

"He attacks another country to seize its riches. What does he take? He takes its riches."

(d) (شر اسة الهجمة تعكس النجاح شر اسة الهجمة تعكس إيه؟.. النجاح. (1)

farā:sit il-hagmah ta3kis in-naga:h. Jarā:sit il-hagmah ta3kis ?eih ?

in-naga: $\hbar$.

"The ferocity of the attack reflects success. What does it reflect? Success."

(هذه القضية بالذات إحنا بنوليها اهتمام كبير ليه؟ لإن الإيطاليين بينا وبينهم علاقات (e) ()

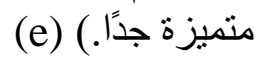

hazihi: il-qaDiyyah biz-za:t ?iћna binu:li:ha ?ihtima:m kabi:r leih ? li?anna il-?iTaliyyi:n binna wi binhum 3ilaqā:t mutamayyizah giddan.

العدد الخامس والعشرون (الجزء الثانى)

()

مجلة كلية التربية- جامعة عين شمس134 
"Why do we give a particular concern to this case? That is because we have very privileged relations with the Italians."

The above extracts show an obvious use of directive questions manifested in the colloquial Arabic question words ?eih, leih and fein, the semantic equivalents of the English interrogative operators what, why and where, respectively. These directives are not intended to get information, i.e. they do not invite the addressees to provide the missing information signaled by what? why? and where?, but require them to believe in what follows. El-Sisi's above questions are expository devices (i.e. asked and answered by the same person) that are not intended to elicit a response from the addressees but rather to communicate certain speaker-interested meanings. That is, they are questions on the semantic level as they encompass the form of interrogative speech acts. However, pragmatically, they are intended to dictate a message through the subsequent answers.

El-Sisi's question-and-answer discourse in (a, b, c) above attempts to inculcate certain presidential meanings, by inviting his addressees to confirm his assumptions concerning the challenges Egypt faces after 30-June revolution, and the achievements he made during two years in presidency. His directive questions carry further pragmatic intents: his competency in rebuilding the state's institutions, removing all obstacles and ending all acts of violence spread all over the country. This competency is emphasized by ElSisi's entailment in (a) that these achievements are realized in a way

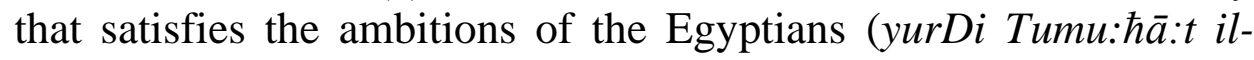
maSriyyi:n).

Extracts (b, c, d, and e) above reflect the extent to which inculcation is explicitly exercised to communicate El-Sisi's intended message. This message is simplified in El-Sisi's answer to the three questions. His lagl xă:Tir baladna in (b), xirha in (c) and in-naga: $\hbar$ in (d), which answer his directives initiated by the interrogative operators leih (why) and ?eih (what), function to convey his loyalty,
2019
العدد الخامس والعشرون (الجزء الثاني)
()
مجلة كلية التربية- جامعة عين شمس135 


\section{Do Directives Always Direct? Cognitive Directives and Meaning}

\section{Inculcation in EI-Sisi's Improvised Speeches}

wisdom and success as a president. Further, El-Sisi's farā:sit ilhagmah ta3kis in-naga: $\hbar$ in (d) shows how two semantically incompatible ideas (i.e. farā:sit il-hagmah and in-naga: $\hbar$ ), which carry oppositional connotations, tend to communicate the successful Sisi.

In (e), a further presidential meaning is targeted, that is, El-Sisi gives much concern to Egypt's relationship with the outside world, and, thus, emphasizes his competency as a president. Again, El-

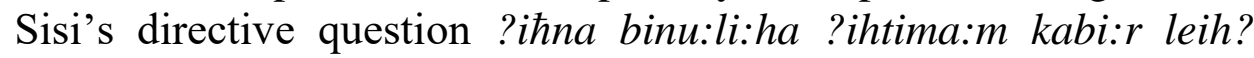
does not seek an answer because he himself provides his interlocutors with the answer for his directive: li? anna il-?iTaliyyi:n binna wi binhum 3ilaqā:t mutamayyizah giddan. El-Sisi's answer attempts not only to communicate the reason beyond his interest in Rigini's case, but also his wise diplomacy in dealing with foreign affairs.

\subsubsection{Yes/no questions}

The second type of directive questions used by El-Sisi is yes/no questions. This type, according to Quirk et al. (quote in Tsui, 2002, p. 90), is "usually formed by placing the operator before the subject and using question intonation." Consider the following extracts:

Extracts 2:

(هل إحنا يعني خلّصنا كل الأزمات المزمنة اللي كانت موجودة؟ إحنا كان عندنا أزمة

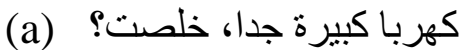

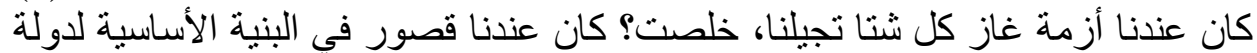

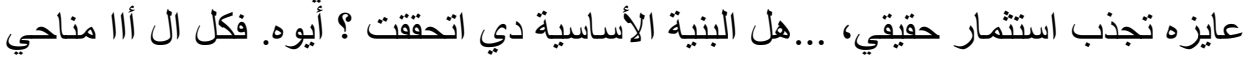

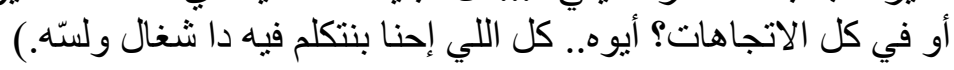

hal ?ihna ya3ni xallaSna kul il-?azama:t illi ka:nit mawgu:dah ? ?ihna ka:n 3andina azmit kahraba kabi:ra giddan, xilSit ? ka:n 3andina azmit\}a:z kul fita tigilna, xilSit ? kan 3andina quSu:r filbiniyah il-asasiyah li-dawlah 3ayzah tigzib ?istismā:r haqi:qi...hal il-biniyah il-asasiyyah di itha?a?it ? ?aywah. fi kul il-manahi: ?aw fi

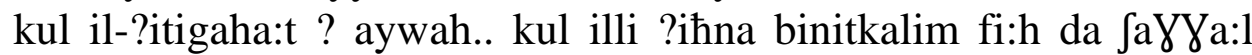
wilissah.

العدد الخامس والعشرون (الجزء الثانى)

مجلة كلية التربية- جامعة عين شمس136 
"Did we solve all our inherited crises? We had a very big electricity problem; does it come to an end? We had a crisis in gas supplementation occurred every winter; does it come to an end? We had insufficiency in the basic infrastructure of a state that seeks to attract true investment; is this basic infrastructure achieved? Yes. Is it realized in all aspects and directions of life? Yes. We achieved all these things, and there still more to be realized."

(ياترى الأمن والاستقر ار ومكافحة الإرهاب مانثي بشكل جيد و لا لأ؟.. أديكم شايفين إحنا

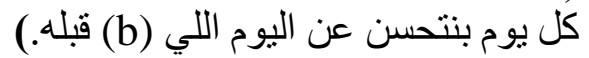
ya tara il-?amn wil-?istiqrā:r wa muka:fahat il-?irha:b mafi bi-fakl gayyid walla la? adi:kum Jaiyfi:n ?ihna kul yu:m binithassin 3an ilyu:m illi ?abluh.

"Do you think that security, stability and counter-terrorism are achieved in a good way or not? You can see how we get better day after another."

$$
\begin{aligned}
& \text { (إنتو فاكرين إنه رد الفعل بتاع المصريين أنا مش سعيد بيه؟ لا أنا سعيد بيه، غيرتكوا } \\
& \text { على بلدكو وخوفكو ا عليها أمر (c) يسعدني. لئاع المدين ويسعد أي وطني حقيقي.) }
\end{aligned}
$$

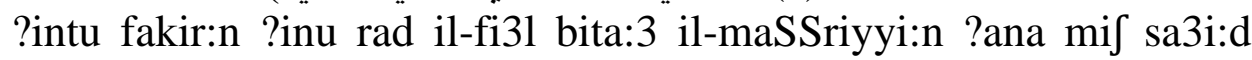
bi:h ? la ?ana sa3i:d bi:h, Yiritku 3ala baladku wi xufku 3aleiha ?amr yis3idni.. wiyis3id ?ay waTani haqi:qi.

"Do you think that I am not happy with the Egyptians reaction? No, I am happy with it; I am happy with your jealousy and concern for your country. This also makes any true loyal happy."

Proceeding with the same mood of directive questions, the above extracts display a yes/no directives represented by the interrogative operators hal, ?intu fakir:n, and ya tara, the semantic equivalents of the auxiliaries used to form yes/no questions in English. These directive questions, though information seekers, do not expect either a 'yes' or 'no' answer on the part of the addressees. They function as inculcation devices through which ElSisi tries to communicate his success in solving many problems that face Egypt and, thus, highlights his achievements as a president.
2019
العدد الخامس والعشرون (الجزء الثاني)
()
مجلة كلية الزبية- جامعة عين شمس137 


\section{Do Directives Always Direct? Cognitive Directives and Meaning}

\section{Inculcation in EI-Sisi's Improvised Speeches}

The list of crises in (a), which are entailed with yes/no questions, are followed by the positive answer denoted by ?aywah, a colloquial Arabic word that indicates a positive response equivalent to 'yes'. Here, it is the competency of a president which is intended to be communicated not the answer of 'yes' or 'no' to whether these crises have been overcome or not. This presidential competency is further emphasized by two things: the use of the past tense of 'be' in ka:nit mawgu:dah, and the use of the colloquial adverb wilissah. The former takes the directive back in time to attribute Egypt's crises to previous regimes, whereas the latter, which is also intended as a speech act of promise, takes it forward to communicate a future commitment for other achievements. This is linguistically

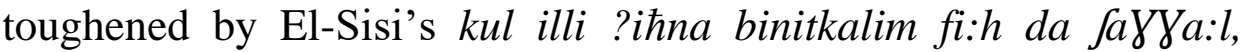
which is intended to show a president whose actions speak louder than words.

Likewise, in extract (b), the same meaning of competency is inculcated through the 'yes/no' question ya tara il-?amn wal?istiqrā:r wa muka:faћat il-?irha:b mafi bi-fakl gayyid walla la?. Again, El-Sisi does not prospect a 'yes' or 'no' answer to his question, but rather he gives another example that supports his capability as a president. He does not directly answer his question with 'yes' or 'no', as is usual in all his yes/no question throughout the speech, but his answer is contextualized in a way that tends to make the question bias towards a positive response. The utterance adi:kum faiyfi:n ?iћna kul yu:m binithassin 3an il-yu:m illi ?abluh functions to cast positivity on El-Sisi's assumption in his yes/no question and, therefore, invites the addressees to confirm a positive meaning of the question. Additionally, the use of the adverbial phrase kul $y u: m$ and the connotatively positive lexis binithassin highlight the question's positive orientation. El-Sisi, therefore, attempts to communicate that security and stability, under his presidency, are better than before.

العدد الخامس والعشرون (الجزء الثان) 2019

مجلة كلية التربية- جامعة عين شمس138 
Further, El-Sisi's yes/no question ?intu fakir:n ?inu rad il-fi3l bita:3 il-maSSriyyi:n ?ana mif sa3i:d bi:h? in (c) above is employed to convey his loyalty. The reaction which El-Sisi means is that of the Egyptians regarding Egyptian/Saudi demarcation of maritime borders; an issue which raises different argumentations among the Egyptians concerning the possession rights of the two islands of Teran and Sanafir. El-Sisi's answer ?ana sa3i:d bi:h functions to create a mutual ground of interest between him and his addressees and reveals a further meaning: the Egyptians' reaction is accepted only when it is classified as jealousy and concern for the country and not as an objection to a political decision.

\subsubsection{Alternative questions}

For Quirk et al. (cited in Tsui, 2002, p. 96), alternative directives are of two types: "the first type resembles a yes/no question and the second a wh-question." Only the first type is represented in the selected speech as is clarified in the following extracts.

Extracts 3:

(هو إحنا هندير أزمة مع السعودية؟ ولا هنديها أرضها؟ .. أزمة يعني إيه؟ يعني هنخش

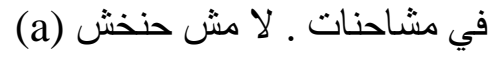

في مشاحنات لإن الغرض هو العزل.. عزل الدولة المصرية.)

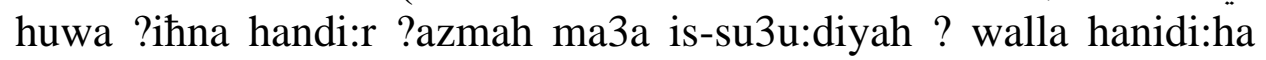

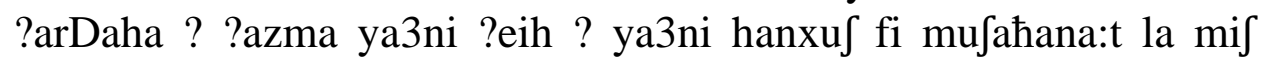
hanxuf fi mufa:hana:t li?anna il-YaraD huwa il-3azl.. 3azl id-dawlah il-maSriyyah.

"Which action will we seek? Running a crisis with Saudi Arabia or returning its lands? What is meant by a crisis? It means that we will engage in conflicts. No, we will never engage in conflicts because this will lead to isolation: to isolate the Egyptian state."

(قضية تقدم مصر ، هي حرية التعبير؟ و لا العمل؟ لأ، تقدم مصر مش بحرية التعبير بس (b) (قدل)

(b) دا بالعمل.

العدد الحامس والعشرون (الجزء الثان) 2019

()

مجلة كلية التربية- جامعة عين ثمس139 
Do Directives Always Direct? Cognitive Directives and Meaning

Inculcation in El-Sisi's Improvised Speeches

qaDiyyat taqaddum maSr hiya huriyyat it-ta3bi:r ? walla il-3amal ? la?, taqaddum maSr mi be-huriyyat it-ta3bi:r bas da bil-3amal. "Which thing will influence Egypt progress? Freedom of expression or work? Egypt's progress is not only determined by the freedom of expression, but also by work."

Unlike ordinary alternative questions that are delivered to invite the addressee to inform the speaker of his choice, directive alternative questions in the above extracts tend to inculcate certain presidential meanings. In extract (a) above, El-Sisi does not want to know the choice of his addressees over the Egyptian-Saudi

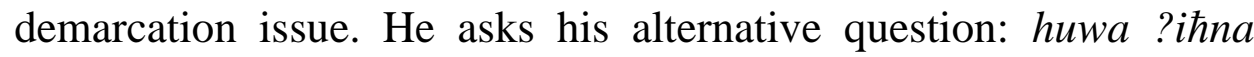
handi:r ?azmah ma3a is-su3u:diyah ? walla hanidi:ha ?arDaha,

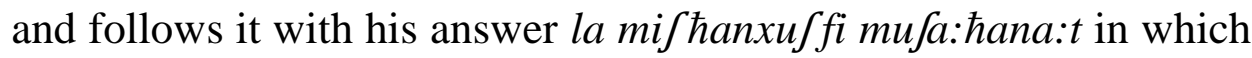
he selects the second alternative in his directive question. He further supports his choice with his argument: li?anna il-YaraD huwa il3azl, 3azl id-dawlah il-maSriyyah. Here, the inculcation process is realized through information acceptance; that is, El-Sisi wants his addressees to accept that returning islands to the Kingdom of Saudi Arabia is crucial for Egypt not to be engaged in more conflicts.

Similarly, the alternative question in (b) carries two choices: huriyyat it-ta3bi:r and il-3amal. Explicitly, the alternative directive communicates that Egypt's progress does not only depend on exercising freedoms, but also on work. This meaning is explicitly communicated by El-Sisi's answer which immediately follows the

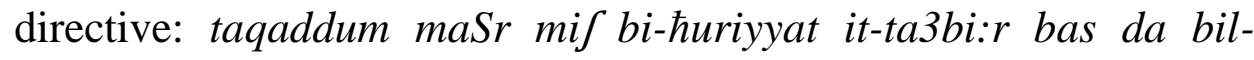
3amal. However, pragmatically, El-Sisi's alternative question is intended to inculcate two meanings: first, he is a knowledgeable president who knows how Egypt can progress in the future; and, second, Egyptians should commit themselves to work. This suggests action and dynamism, and renders El-Sisi as a president who is devoted to work. The following table shows the different linguistic manifestations of directive questions in El-Sisi's speech.

العدد الخامس والعشرون (الجزء الثانى) 2019

()

مجلة كلية التربية- جامعة عين شمس140 
Ayman F. Khafaga

Table 1. Directive questions, their linguistic manifestations and frequency in El-Sisi's speech

\begin{tabular}{|c|c|c|c|c|}
\hline Directives & $\begin{array}{l}\text { Linguistic } \\
\text { manifestation }\end{array}$ & $\begin{array}{l}\text { Interrogative } \\
\text { operator }\end{array}$ & Frequency & Total \\
\hline \multirow[t]{7}{*}{ Questions } & \multirow[t]{5}{*}{ Wh-questions } & إيه & 42 & \multirow[t]{5}{*}{83} \\
\hline & & $\begin{array}{l}\text { ?izzay (how) } \\
\text { إزّاب }\end{array}$ & 14 & \\
\hline & & ليه leih (why) ليه & 13 & \\
\hline & & فين fein (where) & 8 & \\
\hline & & ?imta (when) إمتى ? & 6 & \\
\hline & Yes/no questions & hal (be) هل & 5 & 5 \\
\hline & Alternative questions & $\begin{array}{l}\text { walla (or) } \\
\breve{y}_{g}\end{array}$ & 9 & 9 \\
\hline
\end{tabular}

Table 1 above clarifies that directive questions have three linguistic realizations in the selected speech. The first is wh-question with a total frequency of 83 distributed among five question words: what, how, why, where, and when with frequency of $42,14,13,8$, and 6 , respectively; the second is yes/no question with frequency of 5; and the third is alternative question with frequency of 9 . The frequency distribution also shows that wh-questions are the most frequent directive type used to inculcate particular presidential meanings, particularly the interrogative operator ?eih (what). In all their linguistic manifestations, directive questions go beyond the mere semantic directivity of eliciting responses towards the pragmatic function of inculcating meanings.

\subsection{Directive commands in El-Sisi's speech}

Directive commands have been realized by different linguistic constructions: let-constructions, attention-getters, and direct commands. They are represented in both the affirmative and negative forms.

\subsubsection{Let-constructions}

\section{Extracts 4:}

(اسمحولي أقو لكم إنه النهاردة حديثي معاكم كالعادة.. هو دايما حديث يتسم بالصدق..

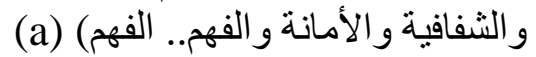

العدد الخامس والعشرون (الجزء الثان) 2019

مجلة كلية الزبية- جامعة عين شمس141 
Do Directives Always Direct? Cognitive Directives and Meaning Inculcation in El-Sisi's Improvised Speeches

?ismahu:li a?ulukum ?inu ?inaharda hadi:si ma3akum kal3adah..huwa dayman hadi:s yatasimu biSSidq waf-Jafafiyah wal ?amanah wal fahm..il-fahm

"Let me tell you that my talk to you today is one that is characterized, as usual, by truthfulness, transparency, honesty and understanding... understanding."

(فاسمولي أكلمكم عن نفسي شوية. أنا باكلم كل المصريين. الناس اللي في الجيش) (b) (فارفي

(b) عارفاني كويس.

fa-?ismaћu:li ?aklimkum 3an nafsi Jwayah. ?ana bakalim kul ilmaSriyyi:n. in-na:s illi fig-geif 3arfa:ni kuwayis.

"Let me talk about myself a little. I talk to all Egyptians. People in the army know me best."

(خلّيني أحسمه أو أنهيه يعني بإن من فضلكم.. أرجو إن الموضوع دا.. أرجوا الموضوع (c)

(c) (c) ما منتكلم فيه تاني

xalli:ni ?aћsimuh ?aw ?anhi:h ya3ni min faDlukum.. ?argu: ?in ilmawDu:3 da manitkallimfi fi:h tani:.

"Let me end such a topic. Please, don't talk about it again."

The above extracts demonstrate a series of let-constructions that are represented by ?ismaћu:li and xalli:ni, the semantic equivalents of the English construction 'let me' which has the semantic force of the imperative. Here, the directive commands are represented by 'let' as their main verb and the first person singular pronoun as their subject. In all the above let-constructions, El-Sisi does not ask for his addressees' permission to allow him to say what he wants to say in $(\mathrm{a}, \mathrm{b})$ or to give him permission to end what he wants to end in (c) because they do not have neither power nor access to give him permission to do or end anything. Through the employment of these imperative-like constructions, El-Sisi foregrounds some intended

العدد الخامس والعشرون (الجزء الثانى) 2019

()

مجلة كلية التربية- جامعة عين شمس142 
meanings that are inferred through the immediately consequent utterances.

In (a) and (b), El-Sisi's let-construction ?ismaћu:li is followed by a proposition in which he assures two meanings: his truthfulness as a president in (a) and his outstanding military background in (b). His repetition to the word il-fahm (understanding) carries a direct call for mutual understanding between him and his addressees. Further, in (b), El-Sisi does not only want to communicate that he is well-known among the armed forces. He, however, tries to extend the cognitive context of his addresses to talk about his past military experiences which, in turn, enables him to inculcate his competency which is witnessed by in-na:s illifig-geif.

Proceeding with the same directive imperative mood, the letconstruction xalli:ni in (c) introduces a proposition in which El-Sisi tends to emphasize that he is powerful enough to end the discussion over the demarcation of the maritime borders issue. Again, his letconstruction is not a permission directive, but rather a device to inculcate the powerful Sisi. Significantly, the attachment of the verb nitkallim to the first person plural pronoun in manitkallim $f i$ and not to the second person plural pronoun, as is usual with ordinary imperative constructions, functions to lessen the directive force of the imperative utterance. Further, the phrase min faDlukum in (c) can be interpreted in two senses: as a politeness marker and as a criticism of the addressees; that is, their frequent speech on the demarcation of Egyptian-Saudi maritime borders, according to ElSisi, will inevitably harm the country. As such, the use of min faDlukum in its second perspective is considered a "tactic of communicating affect by systematic deviation from a norm" (Ervin-

2019 العدد الخامس والعشرون (الجزء الثان)

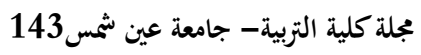


Do Directives Always Direct? Cognitive Directives and Meaning Inculcation in El-Sisi's Improvised Speeches

Tripp, 1976, p. 62). That is, a word/phrase, which is usually used to show politeness, is utilized to reflect impoliteness. This pragmatic dualism is also communicated by the use of the verbs ?aћsimuh and ?anhi:h which are incompatible, both pragmatically and semantically, to the mitigating phrase min faDlukum.

\subsubsection{Attention-getters}

Attention-getter commands explicitly aim to attract the attention of the addressees to what is being said; while, implicitly, they are used to convey certain presidential meanings as is shown in the following extracts.

Extracts 5:

(a) (ونخاف على كل ذرة رمل، خلو ا بالكو كل ذرة رمل (ول)

winxa:f 3ala kul zarrit raml, xallu: balkum kul zarrit raml

"We preserve each grain of sand; pay your attention to this, each grain of sand."

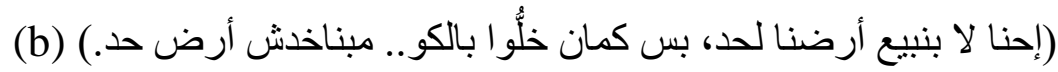

? hna la bin-bi:3 arDina li-had, bas kma:n xallu: balkum, mabnaxudfi arD had.

"We will never sell our land, but pay your attention that we will never take others' land."

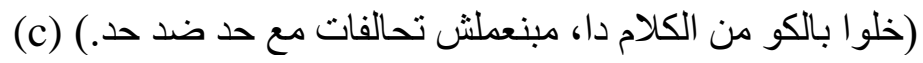

xallu: balkum min il-kala:m da, mab-ni3milfi tahalufa:t ma3a had Did had.

"Be attentive, we never make alliances with anyone against another."

The Arabic idiomatic xallu: balkum in (a), (b) and (c) above, the equivalent of 'pay your attention to' and 'be attentive to' in English, is semantically featured as a directive command whose function is to attract the attention of the interlocutors so as for them to receive the subsequent utterances attentively. El-Sisi's directive
2019
العدد الخامس والعشرون (الجزء الثان)
()
مجلة كلية التربية- جامعة عين شمس144 
command xallu: balkum in (a) reflects the extent to which he is greatly concerned with the security and safety of Egypt. His repetitive phrase kul zarrit raml paves the contextual environment of the speech to address the meaning that he will never surrender one inch of the Egyptian land. This is also emphasized via the use of the synecdochical zarrit raml to refer to the whole Egyptian land. Obviously, El-Sisi's directive command does not only tend to attract his interlocutors' attention to what he is going to say, or to simply tell them that he will never surrender Egypt's land (the two islands). However, his ultimate goal is twofold: first, to communicate that the two islands are not Egyptian; and, second, he is loyal enough not to surrender an inch of the Egyptian lands.

In a similar vein, in extracts (b) and (c), the fair and the diplomatic Sisi is clearly delineated. In (b), the semantically

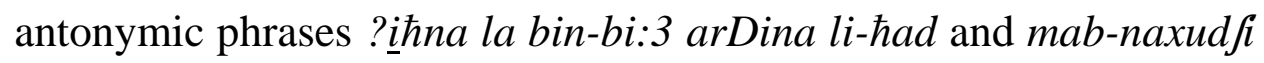
arD $\hbar a d$, which are framed within the directive command xallu: balkum, are significant in shedding light on the fairness of a president who will never sell Egypt's land or seize other's. As such, the Saudi possession right over the two islands can be inferred from El-Sisi's utterances that follow his attention-getter command, specifically the second utterance: mab-naxudfi arD $\hbar a d$. Additionally, extract (c) shows the diplomatic Sisi who assures his addressees that he will never be an ally with someone against another. Significantly, the use of the colloquial Arabic $\hbar a d$, which corresponds to the indefinite partitive pronouns 'someone' and 'anyone' in English, functions to leave identities unknown. This unspecificity tends to present an image of a president whose diplomacy is moderate enough to lead Egypt.

\subsubsection{Direct commands}

Direct commands are presented in the speech both affirmatively, through the use of the bare infinitive; and negatively,
العدد الخامس والعشرون (الجزء الثان) 2019
()
مجلة كلية التربية- جامعة عين شمس145 
Do Directives Always Direct? Cognitive Directives and Meaning Inculcation in El-Sisi's Improvised Speeches

via using 'don't' before the verb as is demonstrated in the following extracts.

Extracts 6:

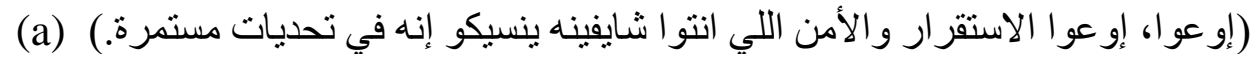
?iw3u: ?iw3u: il-?istiqrā:r wil ?amn illi ?intu Jaifi:nuh yinassiku ?inuh fi tahadiya:t mustamirah

"Don't let stability and security that you have seen make you forget that there are always constant challenges."

(إو عو ا تكونو ا فاكرين إن تعاملكم مع مسألة سد النهضة كان في مصلحتنا.. أبدًا .. أبدًا أبدًا (b) (أبدًا. (أبرًا.

?iw3u: tku:nu fakir:n ?in ta3amulukum ma3a sadd in-nahDa ka:n fi maSlahitna.. abadan.. abadan, abadan, abadan.

"Don't think that your treatment to El-Nahda Dam issue was to our benefit, never."

(c) (إوعو ا يكون مصادركم شبكات التو اصل الاجتماعي.)

?iw3u: yiku:n maSadirkum Jabaka:t it-tawaSul al-?igtima3i

"Don't make social networks as your sources."

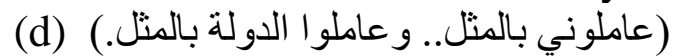

3amlu:ni bil-misl wi 3amlu id-dawlah bil-misl.

"Treat me as well as the state in the same manner as I treat you."

In (a), (b) and (c) above, El-Sisi employs the direct command operator ?iw3u:, the semantic equivalent of the English 'don't', to warn his addressees not to forget the constant challenges Egypt faces in (a), that the Egyptian treatment with the issue of El-Nahda Dam comes against the state's interests in (b), and that Egyptians should not trust the social media as a source of information in (c). Significantly, these explicit warnings, represented by a directive imperative mood, target other implicit meanings: first, El-Sisi manages to achieve security and stability which, for him, were

العدد الخامس والعشرون (الجزء الثانى)

()

مجلة كلية التربية- جامعة عين شمس146 
missed before in (a); second, El-Sisi is a far-sighted president who deals with the problem of El-Nahda Dam in a way that guarantees Egypt's water rights in (b), which is linguistically reinforced by the repetition of the adverb of frequency Abadan (never) (four times in the same utterance); and, third, there is no credibility in social media, and, therefore, take what the truthful Sisi dictates for granted.

In (d), El-Sisi uses two positive directive commands: 3amlu:ni bil-misl and 3amlu id-dawlah bil-misl. In both cases, he does not ask for a specific way of treatment, as is superficially communicated. His command, however, aims to communicate the meaning of a sufferer president who frequently sacrifices for the sake of his country. Obviously, such a sympathetic atmosphere tends to project a suffering image of a president who holds the responsibility of a country burdened with problems, and thus a competency of a president is sought here. The following table shows the different constructions used to communicate directive commands in the speech.

Table 2. Directive commands, their linguistic manifestations and frequency in El-Sisi's speech

\begin{tabular}{|c|c|c|c|c|}
\hline Directive & $\begin{array}{l}\text { Linguistic } \\
\text { manifestation }\end{array}$ & $\begin{array}{l}\text { Imperative } \\
\text { operator }\end{array}$ & Frequency & Total \\
\hline \multirow[t]{5}{*}{ Commands } & Let-constructions & $\begin{array}{l}\text { ?ismahu:li } \\
\text { إسمحولي }\end{array}$ & 7 & \multirow[t]{3}{*}{12} \\
\hline & & $\begin{array}{l}\text { خalli:ni } \\
\text { خلّيني }\end{array}$ & 3 & \\
\hline & & xallu:ni & 2 & \\
\hline & Attention-getters & خلُوا I بالكم & 4 & 4 \\
\hline & Direct commands & $\begin{array}{l}\text { ?iw3u: } \\
\text { إوعوا }\end{array}$ & 7 & 7 \\
\hline
\end{tabular}

العدد الخامس والعشرون (الجزء الثانى)

()

مجلة كلية الزبية- جامعة عين شمس147 
Do Directives Always Direct? Cognitive Directives and Meaning Inculcation in El-Sisi's Improvised Speeches

As shown in table 2 above, directive commands are structurally framed by different imperative operators with a total frequency of 23, distributed among three constructions: let-constructions with frequency of 12 , attention-getters with frequency of 4 , and direct commands with frequency of 7 . Significantly, all imperative constructions are utilized to inculcate certain presidential meanings that revolve around El-Sisi's presidential competency.

\subsection{Directive modality in El-Sisi's speech}

Two constructions of directive modality are used in the selected speech. The first is represented by the use of obligation modals; and the second is manifested in the use of need-statements.

\subsubsection{Obligation modality}

Obligation modality is employed via the Arabic colloquial modal la:zim, the semantic equivalent of the English obligation modals 'must', 'should', and 'have to'. Two constructions of the modal la:zim are manifested in El-Sisi's speech: the first constitutes

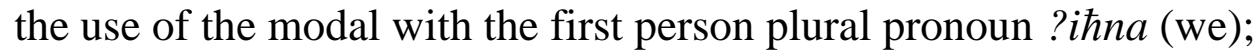
and the second is demonstrated in the use of the modal with the second person plural pronoun ?intu (you). In both cases the modal la:zim is used not only to convey a sense of obligation on the part of the addressees, but also to stimulate a cognitive activity that leads to understand certain arguments in a specific way. The following extracts are examples of the first type.

Extracts 7:

(لازم نكون فاكرين ومش هننسى إن فكرة المؤامرة على الأقل من أهل الثر... و لازم

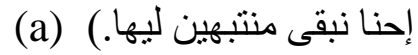

la:zim niku:n fakri:n wi mif haninsa ?in fikrat il-mo?amrah 3ala

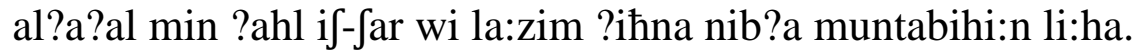

"We should remember and we will never forget that the notion of conspiracy, at least from the villains, is existed. We must pay our attention to this."

العدد الخامس والعشرون (الجزء الثانى)

()

مجلة كلية التربية- جامعة عين شمس148 


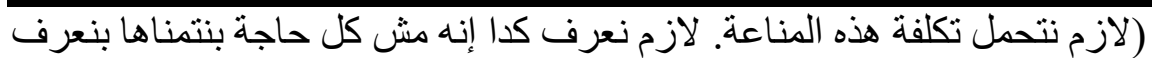

(b) (نعملها (1)

la:zim nithammil taklifat hazihi: al-mana:3ah. la:zim ni3raf kida ?inu mi kul hagah bi-nitmannaha bi-ni3raf ni3milha.

"We must afford the cost of this immunity. We should know that not all that we wish can be realized."

(c) (لازم نحافظ على النسيج دا.)

la:zim niћā:fiz 3ala in-nasi:g dah.

"We must maintain this unity."

As indicated in the above extracts, the Arabic colloquial la:zim is employed to motivate the Egyptians' awareness towards the challenges Egypt faces after 30 th June revolution. Importantly, attaching expressions, such as ni3raf, fakri:n, nithammil,

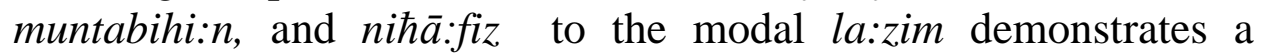
semantic relativity between one of the speech main macropropositions (i.e. challenges following 30th June revolution) and the linguistic way through which it is represented in discourse. Evidently, these expressions are relevant not only to the semantics of the expressed meaning, but also to the process of inculcation as a whole. The semantics of 'know' in ni3raf', of 'remember' in fakri:n, and of 'understand' in muntabihi:n are considered prerequisites of an instruction discourse wherein inculcation is one fundamental device.

Additionally, three superficial meanings with their implicitly intended ones are encoded within the directive obligation mood conveyed by the operator la:zim in the above extracts: First, in (a), there are always conspiracies against Egypt, specifically from ?ahl if-far (the villains). This is semantically counterparted by the implicitly target meaning that Muslim Brotherhood conspires against Egypt. El-Sisi's wi mi haninsa (we will never forget) is a reference which summons Rabia's sit-in events, on the one hand, and a direct invitation to his addressees not to forget what happened, on the other. Second, in (b), Egyptians should afford the obstacles they will face under El-Sisi's presidency, which also targets an

العدد الخامس والعشرون (الجزء الثانى)

()

مجلة كلية التربية- جامعة عين شمس149 
Do Directives Always Direct? Cognitive Directives and Meaning Inculcation in El-Sisi's Improvised Speeches

intended meaning that not all dreams of the Egyptians will be realized. Thus, by announcing hardships, El-Sisi tries to dissociate himself from future criticism. Third, in (c), Egyptians should maintain their unity against any attempt that may undermine them, which is implicitly paralleled to the meaning that Egypt (and of course the president) needs no more protests and, of course, no more revolutions.

The modal la:zim is also used with the second person plural pronoun as is shown in the following extracts.

Extracts 8:

(لازم تكونوا عارفين إن مش ممكن الناس دي تيجي هنا إلا لما يتوفر حاجتين.. أمن

واستقرار.. ثم بنية أساسية (a) متطورة.

la:zim tuku:nu 3arfi:n ?in mi mumkin in-na:s di ti:gi: hina ?illa lamma yitwafar hagtein ?amn wa ?istiqrā:r, summa biniyah ?asasiyyah mutaTawirah.

"You should know that it is difficult for those persons to come to Egypt unless there are two things: security and stability, and an advanced basic infrastructure."

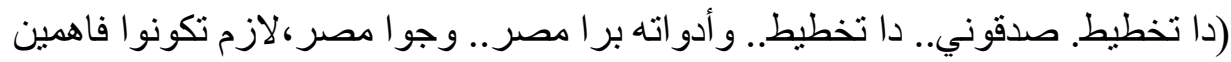

(b) (كدا.)

da taxTi:T Sadda?u:ni..da taxTi:T wi ?adawatuh barra maSr.. wi guwwa maSr, la:zim tuku:nu fahmi:n kida.

"Trust me; this is a plan whose tools are inside and outside Egypt. You must understand this."

The above extracts show the use of la:zim with the second person plural pronoun which is expressed covertly in la:zim tuku:nu 3arfi:n, and la:zim tuku:nu fahmi:n. In (a) and (b), the use of the modal la:zim and the verb yaku:n (be), together with the latent pronoun ?antum in la:zim tuku:nu 3arfi:n, and la:zim tuku:nu fahmi:n has two functions: first, it motivates a sense of obligation on the part of the addressees towards a continuous understanding of El-Sisi's speech. Second, it holds some sort of criticism to the

العدد الخامس والعشرون (الجزء الثانى)

()

مجلة كلية التربية- جامعة عين شمس 150 
Ayman F. Khafaga

addressees (and of course all Egyptians) in case of misunderstanding.

Further, the obligation modal la:zim in the above extracts is not only tended to communicate the meanings that explicitly follow the obligation modal, but also there are other meanings he wants to inculcate. In (a), El-Sisi emphasizes his competency as a president by using the same directive obligation modal la:zim to speak about the future investment in Egypt, which, for him, cannot be achieved unless there are ?amn wa ?istiqrā:r and biniyah ?asasiyah mutaTawirah. Additionally, in (b), the meaning of a knowledgeable president is intended to be communicated. El-Sisi sheds light on the challenges that face Egypt in a reference to the Muslim Brotherhood attempts to plot against Egypt. Also, the use of the verb phrase Sadda?u:ni and the repetitive expression ?adawatuh barra maSr wi guwwa maSr implicitly delineates a president who is acquainted enough to divulge all conspiracies inside and outside Egypt.

\subsubsection{Need-statements}

Two constructions have been used to represent need-statements in El-Sisi's speech: the first is structured by the verb 'need' with the

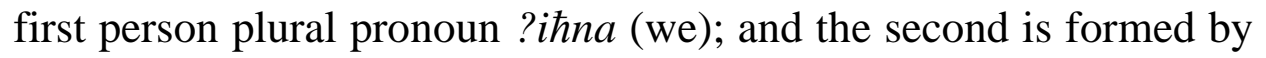
attaching the verb 'need' to the second person plural pronoun ?intu (you). The first type can be displayed in the following extracts.

Extracts 9:

(a) (إحنا محتاجين دايما نحافظ على الكتلة ديت.. كتلة المصريين.)

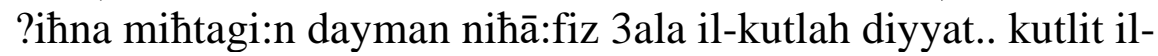
maSriyyi:n.

"We always need to keep this bloc; the Egyptian bloc."

(b) (دايما محتاجين نفتكر الأحداث بتاعة نلاتين يونيو.)

dayman miћtagi:n niftikr il-?aћda:s bita:3it talati:n yuniu:

"We always need to remember the events of June 30th."

(c) (ومتاجين دايمًا نقف ورا الجيش و الثرطة في الحرب دي.) (nar)

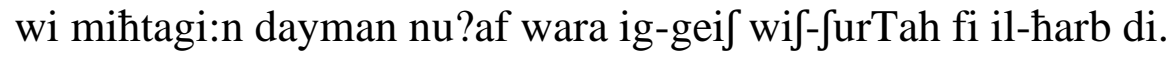

العدد الخامس والعشرون (الجزء الثانى) 2019

()

مجلة كلية التربية- جامعة عين شمس151 
Do Directives Always Direct? Cognitive Directives and Meaning Inculcation in El-Sisi's Improvised Speeches

"We always need to support the army and the police in this war [against terrorism]"

The above extracts show statements of need that are structured

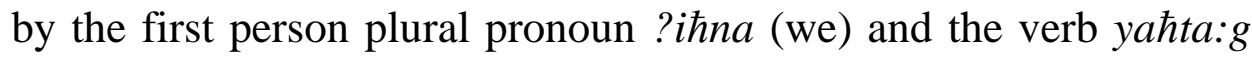
(need) in miћtagi:n to convey obligation which includes both

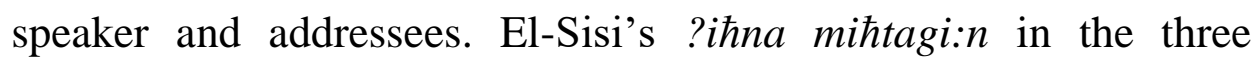
extracts carries an obligation towards three explicit meanings: the necessity of keeping the unity of the Egyptians in (a); the necessity of remembering the events of 30th June in (b); and the necessity of standing side by side with both the police and the army in (c). The sense of obligation is linguistically heightened by two things: first, the use of the frequency adverb dayman (always) which modifies the need-statements in the three extracts to express the highest degree of frequency and to emphasize continuity. Second, the use of the word il-harb (war) in (c) through which El-Sisi tries to describe

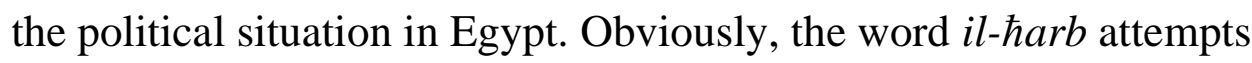
to communicate not only the meaning that Egypt faces many problems after 30th June, but also the meaning of a military president who stands as a brave warrior in the battle field.

The same directive obligation meaning is channeled by the use of need-statements with the second person plural pronoun ?intu (you) as is shown in the following extracts.

Extracts 10:

(طمس الحقيقة وتزييف الو اقع، ودا اللي إنتو محتاجين يا مصريين دايما تنتبهو اليه. )

(a)

Tams il-haqiqa wa tazyi:f il-wā:qi3, widah ?illi ?intu miћtagi:n ya maSriyyi:n dayman

العدد الخامس والعشرون (الجزء الثانى)

مجلة كلية التربية- جامعة عين شمس152 
tintibhu li:h

"Blurring the truth and falsifying reality are the two things you, Egyptians, need to be always attentive to."

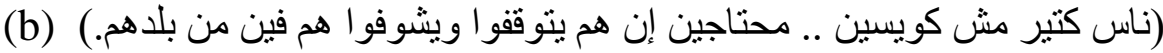

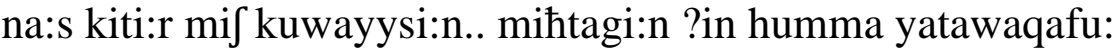

wiyfufu: humma fein min baladhum.

"There are many bad people. They need to stop and rethink their relation with their country."

Two structures of need statements are presented in the above extracts. The first is formed by the second person plural pronoun ?intu and the verb yahta:g in ?intu mittagi:n; and the second is structured by the third person plural pronoun humma and the verb

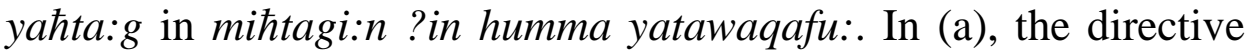
modality aims to create a sense of warning through which El-Sisi attempts to motivate his addressees' attention so as not to be deceived by the lies launched every now and then. Here, the addressees are directed to one meaning: Egyptians should not trust any biased information against their country and/or their president.

Similarly, in (b), the obligation mood is directed towards a third group. The need-statement miћtagi:n ?in humma yatwaqafu: is a direct message to those who is plotting against Egypt to rethink their position and return to the mantle of the state again. Now, a further implicit meaning is attempted to be inculcated. It is the meaning of a sober and tolerant president who gives a second chance and extends a helping hand to others. This atmosphere of leniency is linguistically heightened by the use of the euphemistic expression mif kuwayysi:n (not good) to describe those maneuvering against Egypt instead of using sayy?i:n (bad). Crucially, the directive modality encoded in la:zim and miћtagi:n creates an obligation commitment (cognitive) intended to inculcate specific meanings that represent both epistemic modality in expressions constituting the

العدد الخامس والعشرون (الجزء الثانى) 2019

مجلة كلية التربية- جامعة عين شمس153 
Do Directives Always Direct? Cognitive Directives and Meaning

Inculcation in El-Sisi's Improvised Speeches

operator mihtagi:n and deonetic modality in expressions carrying the operator la:zim. The following table displays the different constructions used to convey directive modality in the speech.

Table 3. Directive modality, their linguistic manifestations and frequency in El-Sisi's speech

\begin{tabular}{|c|c|c|c|c|c|c|c|}
\hline \multirow{2}{*}{$\begin{array}{l}\text { Directives } \\
\text { Modality }\end{array}$} & \multirow{2}{*}{$\begin{array}{l}\begin{array}{l}\text { Linguistic } \\
\text { manifestation }\end{array} \\
\text { Obligation } \\
\text { modals }\end{array}$} & \multirow{2}{*}{$\begin{array}{l}\begin{array}{l}\text { Modality } \\
\text { operator }\end{array} \\
\text { la:zim } \\
\text { لازم }\end{array}$} & \multicolumn{2}{|c|}{ Pronominal variation } & \multirow{2}{*}{$\begin{array}{l}\text { Fr. } \\
13\end{array}$} & \multirow{2}{*}{$\begin{array}{l}\begin{array}{l}\text { Examples in } \\
\text { context }\end{array} \\
\text { la:zim tuku:nu: } \\
\text { musta3iddi:n }\end{array}$} & \multirow{2}{*}{$\begin{array}{l}\text { Total } \\
22\end{array}$} \\
\hline & & & $\begin{array}{l}\text { ?intu } \\
\text { 'you' }\end{array}$ & overt & & & \\
\hline & & & & latent & 0 & & \\
\hline & & & $\begin{array}{l}\text { ?ihna } \\
\text { 'we' }\end{array}$ & overt & 2 & $\begin{array}{l}\text { la:zim ?ihna } \\
\text { niku:n } \\
\text { muntabihi:n }\end{array}$ & \\
\hline & & & & latent & 5 & $\begin{array}{l}\text { la:zim nihā:fiz } \\
\text { 3ala in-nasi:g } \\
\text { dah }\end{array}$ & \\
\hline & & & $\begin{array}{l}\text { humma } \\
\text { 'they' }\end{array}$ & overt & 2 & $\begin{array}{l}\text { la:zim } \\
\text { yibuSSu: } \\
\text { yifu:fu: il- } \\
\text { hikayah di } \\
\text { hallaha ?eih }\end{array}$ & \\
\hline & & & & latent & 0 & & \\
\hline & $\begin{array}{l}\text { Need- } \\
\text { statments }\end{array}$ & $\begin{array}{l}\text { mihtagi:n } \\
\text { محتاجين }\end{array}$ & $\begin{array}{l}\text { ?iћna } \\
\text { 'we' }\end{array}$ & overt & 4 & 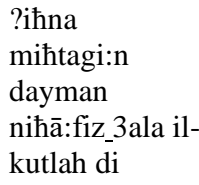 & 10 \\
\hline
\end{tabular}

العدد الخامس والعشرون (الجزء الثان) 2019

()

مجلة كلية التربية- جامعة عين شمس154 
Ayman F. Khafaga

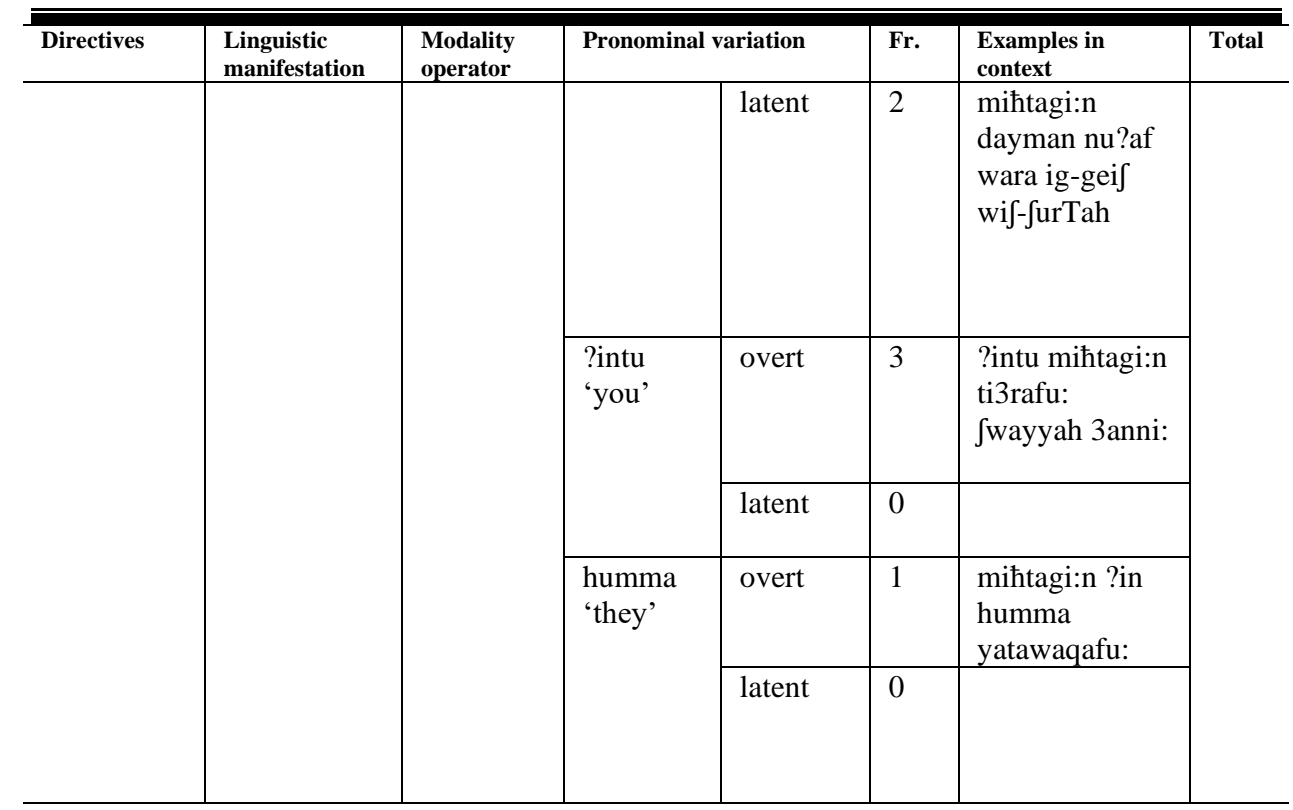

Note. 'Fr.' means frequency

Table 3 above demonstrates that directive modality has linguistically been realized by the obligation modal la:zim with total frequency of 22 distributed between three pronouns: the second person plural pronoun ?intu with frequency of 13, the first person

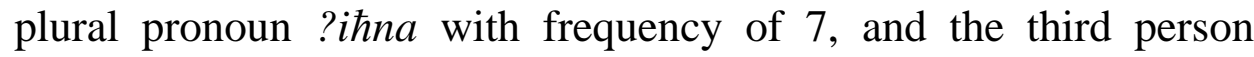
plural pronoun humma with frequency of 2. The table also shows that directive modality is encoded in the selected speech by means of need-statements that are represented by the colloquial Arabic obligation-carrier lexis miћtagi:n with a total frequency of 10.6

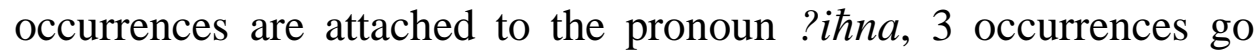
with ?intu, and only one occurrence is presented with humma. Indicatively, among the total occurrences of obligation modality and need-statements (32 occurrences), 25 occurrences express obligation and necessity by attaching the modality operators to overt pronouns, whereas the same notion of obligation is conveyed by latent pronouns in only 7 occurrences. This indicates that El-Sisi attempts to communicate his intended meanings by means of different pronominal variations that function as a marker of intentional

العدد الخامس والعشرون (الجزء الثانى)

مجلة كلية التربية- جامعة عين شمس 155 


\section{Do Directives Always Direct? Cognitive Directives and Meaning}

\section{Inculcation in EI-Sisi's Improvised Speeches}

inculcation, expressed both overtly and covertly, to represent the different participants in discourse: the speaker, the addressees and the third party. Indicatively, associating the different forms of pronouns with the directive modalities constitutes what von Fintel (2006, p. 25) terms "compositional interaction," which means that "modal expressions can compositionally interact with other expressions" to contribute, as is the case for this paper, to the overall compositional content of discourse (ibid, p. 25).

\section{Findings and discussion}

The above analysis of directives in El-Sisi's speech demonstrates a number of findings as follows:

First, unlike the majority of studies on directives (e.g. Searle, 1969, 1976, 1979; Grice, 1975; Lyons, 1977, 1983; Tsui, 2002; Sinclair \& Coulthard, 2002; Ryckebusch \& Marcos, 2004; Condoravdi \& Lauer, 2012; Leech, 2014; Kent \& Kendrick, 2016) who argue that the main function of directives is to request a verbal and/or physical response, the above analysis shows that directives in the selected speech, be they questions, commands, or modality, do not aim to "get the hearer to do something [textual/physical]" (Searle, 1976, p. 11), "produce actions" (Ross, 1968, p. 38), or perceived as bald on-record threats to one's face (Brown \& Levinson, 1987; Leech, 1983). That is, they do not seek information (in the case of questions), initiate a verbal/nonverbal action (in the case of commands) or communicate obligation (in the case of obligation modality). Directives, in light of this paper, instigate a cognitive activity on the part of hearers rather than a textual or physical one. This cognitive activity is motivated by three things: first, by El-Sisi's desire that his intended meanings will be absorbed quite willingly on the part of his addressees (Thornburg \& Panther's (1997) 'Before' ); second by El-Sisi's use of the three types of directives: directive questions, which are linguistically manifested in wh-questions, yes/no questions and alternative questions; directive commands, which are represented by direct imperatives,

العدد الخامس والعشرون (الجزء الثالن) 2019

()

مجلة كلية التربية- جامعة عين شمس156 
attention getters and let-constructions; and directive modality, which is encoded in obligation modals and need statements(Thornburg \& Panther's (1997) 'Core'); and third, by the expected realization of the intended meanings beyond the directive code (Thornburg \& Panther's (1997) 'After') (see Subsection 2.3). Here, it can be proposed that the ultimate goal of El-Sisi's directives is to make his interlocutors accept and concede a specific argument in a particular way and, therefore, the focus of this paper is on the cognitive dimension of directives rather than the textual or physical one. Consider the following figure.

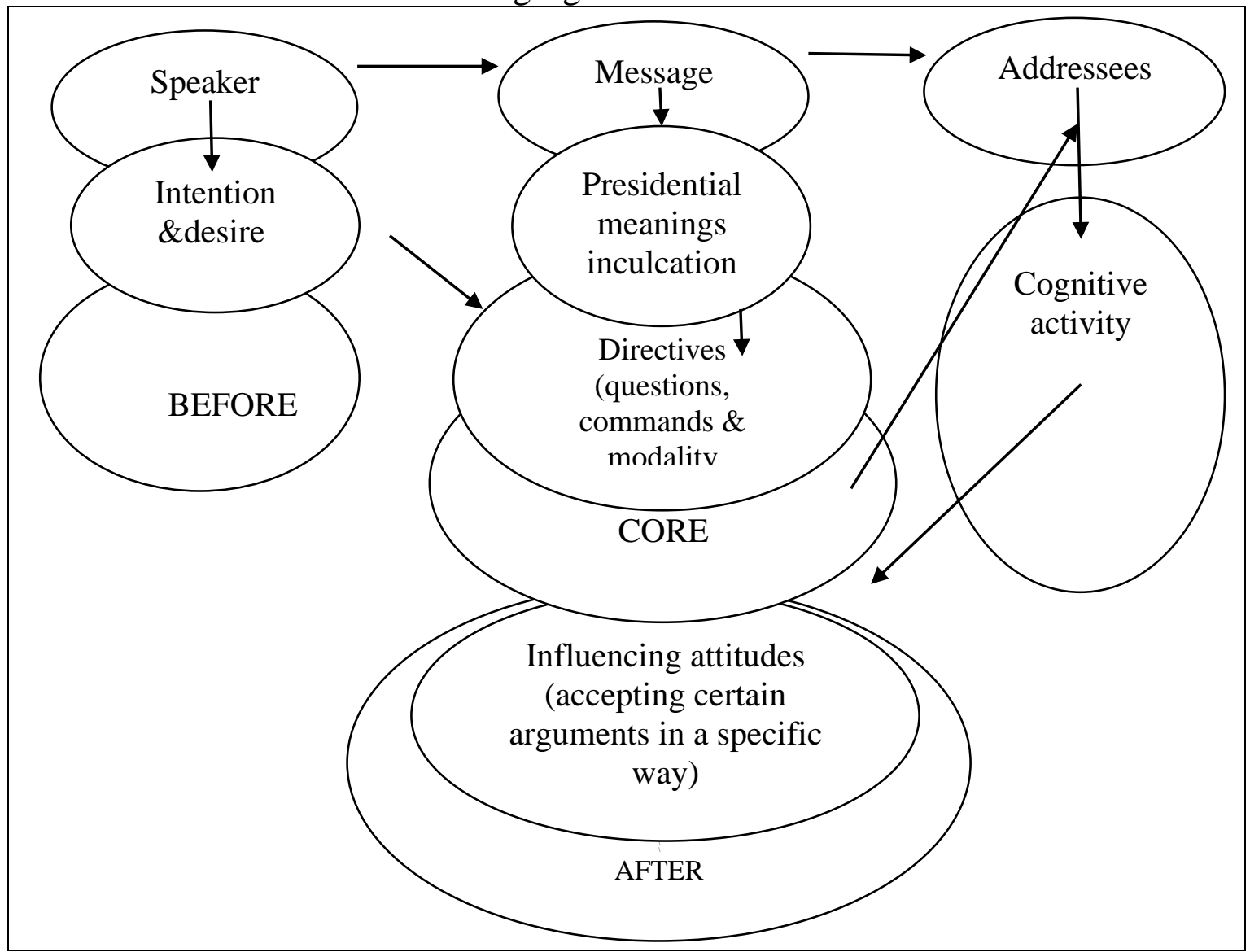

Figure 1: Scenario of meaning inculcation through directives in El-Sisi's speech

$$
\begin{aligned}
& \text { العدد الخامس والعشرون (الجزء الثان) } 2019 \\
& \text { مجلة كلية التربية- جامعة عين ثمس157 }
\end{aligned}
$$




\section{Do Directives Always Direct? Cognitive Directives and Meaning}

\section{Inculcation in EI-Sisi's Improvised Speeches}

The above figure shows the scenario of meaning inculcation in ElSisi's speech. As demonstrated in the figure above, El-Sisi's directives are intentionally used to inculcate certain meanings with a desire to influence a cognitive change in behavior on the part of his addressees that allows the acceptance of the intended meanings in a particular way. This cognitive change constitutes Thornburg and Panther' (1997) three phases of cognitive meaning construction: before, core and after. Importantly, the cognitive activity sought beyond using directives in this paper makes it reconcile with Hyland's (2002) argument that the cognitive act is one type of activities imposed by directives which, for him, is considered "the highest degree of imposition" (ibid., p. 218).

Second, directive questions are not utilized to create "a position for an answer," but to create "openings for discourse continuation or termination" (Ervin-Tripp, 1976, p. 49). This is totally what is done in the selected speech; (cognitive) directive questions, however interrogative, are not information-seeking. They are not about individuals, times, manners, reasons and so on, as is the case for ordinary questions. Rather, they are employed to maintain discourse in a way that guarantees the inculcation of some intended meanings that are linguistically injected in the subsequent answers, both explicitly and implicitly. As such, the imposition force of textual and/or physical directivity is missed in El-Sisi's questions, and, therefore, allows the addressees to ignore the interpersonal function in replying, and to engage in a cognitive act to arrive at the intended meaning encoded in the directive code.

Third, the question-and-answer discourse, which is dominated by directive questions, helps sustain the semantic relativity between the explicit meanings in the speech and the implied meanings of the speaker. This propositional relativity is conveyed by the president's subsequent answers that are contextually framed to communicate the surface meanings targeted by these questions and the intended meanings that are cognitively forgrounded by the subsequent

العدد الخامس والعشرون (الجزء الثالن) 2019

()

مجلة كلية التربية- جامعة عين شمس158 
answers. This propositional connectivity between the explicit and the implicit (i.e. the surface meanings of questioning and the implied meanings beyond answering) is referred to by Simons, Tonhauser, Beaver, and Roberts (2010) who argue that a proposition is perceived to be relative to a question only when it contextually constitutes an answer to such a question. The harmonious threading of the question-answer discourse and surface-implied meaning also functions to "connect the linguistic and the pragmatic side of discourse in a natural way" (Benz \& Jasinskaja, 2017, p. 178).

Fourth, El-Sisi uses what Jakobson (1997) terms "selection and combination" (p. 75, italics in original) within a directive mood to inculcate his intended meanings. Selection and combination, for Jakobson (ibid, p. 75), are considered "the two basic modes of arrangement used in verbal behavior." This strategy allows speakers to maintain certain meanings by selecting and combining particular words that are "semantically cognate" (ibid., p. 75) to the macropropositions of the speech and the intended meanings of the speaker. Obviously, the analysis of the selected speech identifies four macropropositions: (i) El-Sisi has a distinguished military background; (ii) challenges following 30th June revolution; (iii) achievements during two years and a half in presidency; and (iv) Egypt's relationships with the outside world, which is manifested in three discourse subtopics: (a) the demarcation of Egypt's and Saudi Arabia's maritime borders, (b) El-Nahda Dam in Ethiopia, and (c) Regini's killing in Egypt. The four macropropositions have semantically been contextualized by means of selection and combination. The following table clarifies how lexical selection and combination activate the semantic relativity between discourse form and propositional content. 


\section{Do Directives Always Direct? Cognitive Directives and Meaning Inculcation in EI-Sisi's Improvised Speeches}

\section{Table 4. Selection and combination characterizing the four}

macropropositions in El-Sisi's speech

\begin{tabular}{|c|c|c|c|}
\hline $\begin{array}{c}\text { Macroproposi } \\
\text { tion }\end{array}$ & Selected lexis & Freq. & Indicative selection in combination \\
\hline \multirow{16}{*}{$\begin{array}{l}\text { El-Sisi has a } \\
\text { distinguished } \\
\text { military } \\
\text { background. }\end{array}$} & \multirow{4}{*}{ الجيش } & \multirow[t]{4}{*}{14} & 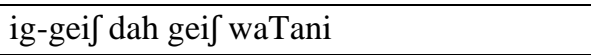 \\
\hline & & & ?adabiya:t ig-geif wa?axlā:qiyyatuh \\
\hline & & & quwat ig-geif \\
\hline & & & ig-geif mas?u:1 \\
\hline & \multirow{3}{*}{ جيش } & \multirow[t]{3}{*}{6} & gei $\int \mathrm{maSr}$ \\
\hline & & & geif waTani \\
\hline & & & geif waTani fari:f \\
\hline & maba:di? مبادئ & 8 & alqiyam wal-mabadi? \\
\hline & خريص حari:S & 7 & sawabit ?iћna hari:Si:n 3aleiha \\
\hline & qiyam قيم & 6 & al-qiyam wal-mabadi? \\
\hline & \multirow{3}{*}{$\begin{array}{l}\text { af-fafafiyah } \\
\text { الثفافية }\end{array}$} & \multirow[t]{3}{*}{3} & af-safafiyah wal-?amanah \\
\hline & & & al-wuDu:ћ waf-fafafiyah \\
\hline & & & bi-muntaha af-fafafiyah \\
\hline & \multirow{2}{*}{$\begin{array}{l}\text { al-?amanah } \\
\text { الأمانة }\end{array}$} & \multirow[t]{2}{*}{3} & ?aћā:fiz 3ala hazihi: al-?amanah \\
\hline & & & al-?amanah di hats?il 3aleiha \\
\hline & aS-Sidq الصدق & 1 & yattasimu biS-Sidq \\
\hline \multirow{15}{*}{$\begin{array}{l}\text { Challenges } \\
\text { following 30th } \\
\text { June } \\
\text { revolution }\end{array}$} & \multirow{3}{*}{$\begin{array}{l}\text { أزمة } \\
\text { azmah }\end{array}$} & \multirow[t]{3}{*}{9} & 3andina ?azmit Ya:z \\
\hline & & & 3andina ?azmit kahrabah \\
\hline & & & ?azmah ma3a is-su3u:diyah \\
\hline & \multirow{3}{*}{ af-far } & \multirow[t]{3}{*}{6} & ?ahl if-Jar \\
\hline & & & quwa if-sar \\
\hline & & & if-jar wi ?ahluh \\
\hline & \multirow{2}{*}{$\begin{array}{l}\text { taћaddiya:t } \\
\text { تحديات }\end{array}$} & \multirow[t]{2}{*}{5} & taћaddiya:t mustamirah \\
\hline & & & kiti:r min it-tahaddiya:t \\
\hline & \multirow{3}{*}{$\begin{array}{l}\text { ?irha:b } \\
\text { إرهاب }\end{array}$} & \multirow[t]{3}{*}{4} & da ?irha:b \\
\hline & & & al-3anā:Sir al-?irhabiyah \\
\hline & & & muka:fahat al-?irha:b \\
\hline & \multirow{3}{*}{$\begin{array}{l}\text { ?ifkaliya:t } \\
\text { إثكاليات }\end{array}$} & \multirow[t]{3}{*}{3} & 3andina kiti:r ?ifkaliya:t mawgu:dah \\
\hline & & & ?ijkaliya:t id-duniya \\
\hline & & & il-?ifkaliya:t illi mawgu:dah \\
\hline & fawDah & 2 & ?iћna 3andina fawDah \\
\hline
\end{tabular}

العدد الخامس والعشرون (الجزء الثاني) 2019 
Ayman F. Khafaga

\begin{tabular}{|c|c|c|c|}
\hline & فوضى & & fawDah fi kul hagah \\
\hline & fasa:d فساد & 1 & 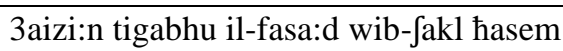 \\
\hline & $\begin{array}{l}\text { salbiya:t } \\
\text { سلبيات }\end{array}$ & 1 & kiti:r min is-salbiya:t \\
\hline & $\begin{array}{l}\text { maxā:Tir } \\
\text { مخاطر }\end{array}$ & 1 & mahamini: ? ?ay max ā:Tir \\
\hline \multirow{24}{*}{$\begin{array}{l}\text { Achievements } \\
\text { during two } \\
\text { years and a } \\
\text { half in } \\
\text { presidency. }\end{array}$} & \multirow{2}{*}{$\begin{array}{l}\text { mu?assasa:t } \\
\text { مؤسسات }\end{array}$} & \multirow[t]{2}{*}{13} & mu?assasa:t id-dawlah \\
\hline & & & mu?assasa:t 3ari:qah \\
\hline & \multirow{3}{*}{$\begin{array}{l}\text { il-3amal } \\
\text { العمل }\end{array}$} & \multirow[t]{3}{*}{11} & ma3niyi:n bil-3amal \\
\hline & & & hagm il-3amal illi tam ?ingazuh \\
\hline & & & furaS il-3amal illi hayiduha lin-na:s \\
\hline & \multirow{3}{*}{$\begin{array}{l}\text { naga: } \\
\text { نجاح }\end{array}$} & \multirow[t]{3}{*}{7} & naga:h wa taqaddum \\
\hline & & & min naga: $\hbar$ li-naga: $\hbar$ \\
\hline & & & ta3kis in-naga: $\hbar$ \\
\hline & \multirow{3}{*}{$\begin{array}{l}\text { hurriyah } \\
\text { حرية }\end{array}$} & \multirow[t]{3}{*}{6} & ћurriyat it-ta3bi:r \\
\hline & & & ћurriyat il-?i3tiqā:d \\
\hline & & & di hurriyah haqiqiyyah \\
\hline & \multirow{2}{*}{$\begin{array}{l}\text { ?istiqrā:r } \\
\text { إسنققرار }\end{array}$} & \multirow[t]{2}{*}{5} & al-?istiqrā:r wal-?amn \\
\hline & & & salamha wa ?istiqrarha \\
\hline & \multirow{2}{*}{$\begin{array}{l}\text { maJa:ri:3 } \\
\text { مشاريع }\end{array}$} & \multirow[t]{2}{*}{4} & magmu:3ah min il-mafa:ri:3 \\
\hline & & & al-maja:ri:3 al-qawmiyah \\
\hline & \multirow{2}{*}{$\begin{array}{l}\text { ?istisma:r } \\
\text { إستثمار }\end{array}$} & \multirow[t]{2}{*}{4} & ?istismā:r haqi:qi \\
\hline & & & fi:h ?istismā:r \\
\hline & \multirow{2}{*}{$\begin{array}{l}\text { taqaddum } \\
\text { تقدم }\end{array}$} & \multirow[t]{2}{*}{4} & taqaddum maSr \\
\hline & & & naga:ћ wa taqaddum \\
\hline & الأمن il-?amn & 4 & il-?amn wal-?istiqrā:r \\
\hline & زراعة zira:3ah & 3 & al-mafa:ri:3 al-xā:Sah bezzirā:3ah \\
\hline & \multirow{2}{*}{$\begin{array}{l}\text { maSa:ni3 } \\
\text { مصانع }\end{array}$} & \multirow[t]{2}{*}{3} & maSā:ni3 ruxa:m \\
\hline & & & taTwi:r li-maSa:ni3 taniyah \\
\hline & $\begin{array}{l}\text { dimuqrā:Tiyah } \\
\text { ديموقر اطية }\end{array}$ & 2 & dawlah dimuqrā:Tiyah ћadi:sah \\
\hline \multirow{7}{*}{$\begin{array}{l}\text { Egypt's } \\
\text { relationship } \\
\text { with the } \\
\text { outside world. }\end{array}$} & \multirow{3}{*}{$\begin{array}{l}\text { al-hudu:d } \\
\text { الحدود }\end{array}$} & \multirow[t]{3}{*}{18} & ћudu:d il-miyah al-?iqtiS ā:diyah \\
\hline & & & ta3li:m il-hudu:d il-bahariyah \\
\hline & & & tarsi:m il-hudu:d ma3a is-su3u:diyah \\
\hline & \multirow{2}{*}{$\begin{array}{l}\text { al-ћuqu:q } \\
\text { الحقوق }\end{array}$} & \multirow[t]{2}{*}{14} & nu3Ti il-huqu:q li-?aShabha \\
\hline & & & 3adam it-tafri:T fi huqu:qina \\
\hline & \multirow{2}{*}{$\begin{array}{l}\text { 3ilaqā:t } \\
\text { علاقات }\end{array}$} & \multirow[t]{2}{*}{8} & bina:? 3ilaqā:t ma3a kul id-diwal \\
\hline & & & $\begin{array}{l}\text { 3ilaqā:tuna mabniyyah 3ala qiyam wa } \\
\text { mabadi? }\end{array}$ \\
\hline
\end{tabular}

العدد الخامس والعشرون (الجزء الثانى) 2019 
Do Directives Always Direct? Cognitive Directives and Meaning Inculcation in El-Sisi's Improvised Speeches

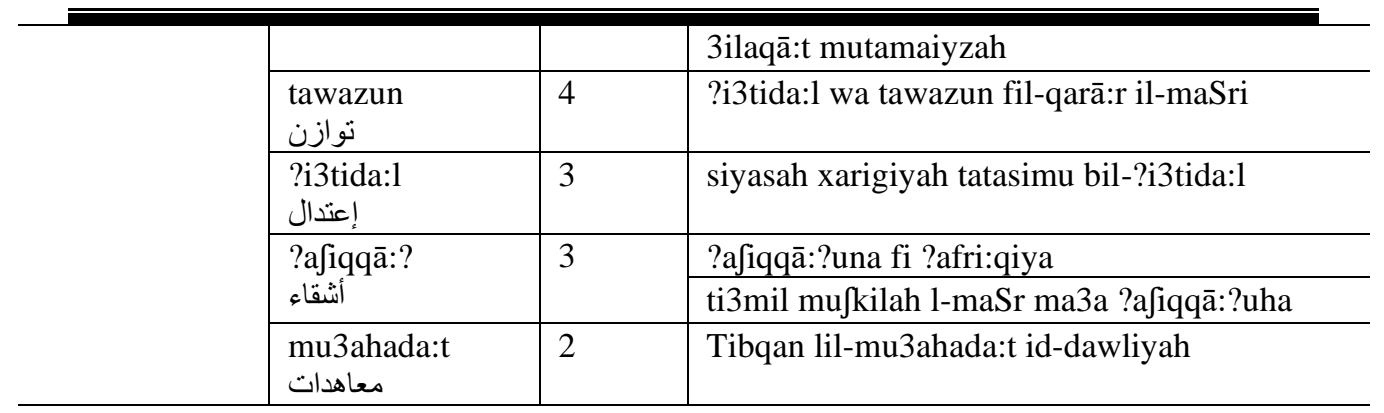

Note. 'Freq' means frequency

Table 4 above demonstrates that the four macropropositions have been semantically lexicalized (i.e. via selection and combination) in a way that facilitates the inculcation of El-Sisi's meanings. For example, the lexis ig-geif is discursively combined with waTani, fari:f, quwat, ?adabiya:t, ?axlā:qiya:t, and mas?u:l. This positive combination tends to highlight the powerfulness and veracity of the Egyptian army and, certainly, of El-Sisi as a previous Field Marshal in this military institution. Similarly, the magnitude of challenges after 30th June revolution is represented by the semantic selection and combination in tahaddiya:t mustamirah, 3andina fawDah, kiti:r min is-salbiya:t,etc. Further, the same selection and combination strategy is employed to shed light on the president's achievements. This is clearly shown in expressions like ma3niyi:n bi-l3amal, min

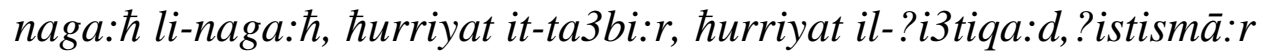

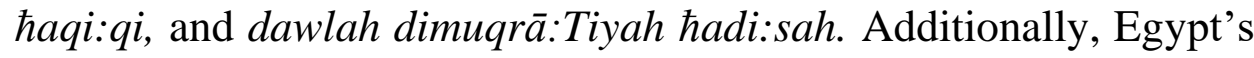
foreign relationships is highlighted through selection and

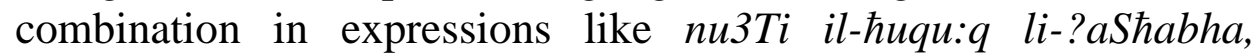
3ilaqā:t mutamaiyzah, i3tida:l wa tawazun fil-qarā:r il-maSri, and siyasah xarigiyah tatasimu bil-?i3tida:l. Indicatively, the four macropropositions and their lexicalized selection, together with the positive and/or negative combinations are linguistically biased towards one main meaning: the presidential competency of El-Sisi, the core goal of meaning inculcation in the speech.

العدد الخامس والعشرون (الجزء الثانى)

مجلة كلية التربية- جامعة عين شمس162 
The semantic relativity between the selected words and their combinations, which has been shown in tables 4 has been strengthened by Norén and Linell's (2007) theory of "meaning potentials" which is used to describe "the connection between word meaning and context" (p. 389). This theory advocates the assumption that particular lexical items and expressions are used in combination with contextual properties of texts to communicate the situated meanings of language users. This harmonious connection between lexical items and contextual factors of texts is also similar in nature to Gibson's (1979, cited in Norén \& Linell, 2007, p. 389) "semantic affordance" theory, which also proposes that lexical items provide language users with affordances of meanings.

Here, one can summon van Dijk's (1991) argument that "discourse meanings influence many aspects of surface structures, such as lexical selection" (p. 204). That is, the selection and combination process is influenced by the four macropropositions of the speech, and, therefore, a connection between "mental representations" and "linear sequence of words" is realized (Levelt, 1982, cited in van Dijk, 1991, p. 204). This semantic connectivity is characterized by a "contextual monitoring" of the "textual structures" of discourse (van Dijk, 1991, p. 205). Lexical selection, for van Dijk (ibid., p. 210), is "simply part of a broader pattern of contextualized ideological control of the meaning of text and talk". Thus, El-Sisi's specific selection of words and their semantic combination function to contextualize the directive mood towards certain political meanings.

Fifth, El-Sisi's directives are structured around what Sinclair and Coulthard (2002) term "frame" and "focus" (p. 3, italics in original). These are represented by the use of some words and/or phrases in order to introduce a new proposition and to mark the importance of what will follow. Among these expressions, which are employed in the speech, are xallu:ni a?ulukum, ?ismahu:li a? ulukum and 3aiz a? ulukum. For Sinclair and Coulthard (ibid., p. 3), expressions like these are used to "indicate boundaries" in 
Do Directives Always Direct? Cognitive Directives and Meaning

Inculcation in EI-Sisi's Improvised Speeches

spoken discourse. These expressions, though carrying a permission directive, are used for further discourse functions: first, they are considered discourse exchange tools used to indicate the end of a proposition and the beginning of another; and second, they tend to attract the addressees' attention to what is going to be delivered. Accordingly, El-Sisi's directives are cataphoric to a later utterance. That is, in order for the addressees to understand the message a directive carries, they need not only the directive operators used to introduce a directive (frame), but also the consequent utterances that follow (focus).

Sixth, El-Sisi recurrently uses the vocative il-maSriyyi:n (Egyptians) in accompany with his directive commands and modality. For Brinton (1996), vocatives communicate two functions: interpersonal, when they indicate respect and deference towards the addressees; and conversational, when they are used to attract the attention of the addressees. El-Sisi uses the vocative ilmaSriyyi:n not only to express his attitudes towards his addressees, but also to instigate them to do or to stop an action. This correlates with Taavitsainen's (1995, p. 439) argument that vocatives are sometimes directed at the addressees "to acquire a desired reaction" which, for her, "may serve communicative intentions more broadly." The vocative il-maSriyyi:n, with its discourse variation in the selected speech, has three pragmatic functions: first, to show respect and deference; second, to attract the attention of the addressees to the importance of the following and/or preceding utterances; and third, to express intimacy and solidarity. Consider the following table.

العدد الخامس والعشرون (الجزء الثانى) 
Ayman F. Khafaga

Table 5. The vocative il-maSriyyi:n in El-Sisi's speech

\begin{tabular}{|c|c|c|c|c|}
\hline Vocatives & $\begin{array}{l}\text { Variation in } \\
\text { discourse }\end{array}$ & Frequency & Pragmatic function & Total \\
\hline \multirow[t]{5}{*}{$\begin{array}{l}\text { il- } \\
\text { maSriyyi:n } \\
\text { المصريين }\end{array}$} & $\begin{array}{l}\text { il-maSriyyi:n } \\
\text { المصريين }\end{array}$ & 29 & $\begin{array}{l}\text { Interpersonal: } \\
\text { shows respect and } \\
\text { deference }\end{array}$ & \multirow{5}{*}{44} \\
\hline & $\begin{array}{l}\text { ya maSriyyi:n } \\
\text { يصريين }\end{array}$ & 9 & $\begin{array}{l}\text { Conversational: } \\
\text { attracts attention }\end{array}$ & \\
\hline & $\begin{array}{ll}\text { ?iћna il- } \\
\text { maSriyy:in } \\
\text { إحنا المصريين }\end{array}$ & 3 & $\begin{array}{l}\text { Interpersonal: } \\
\text { expresses intimacy } \\
\text { and solidarity }\end{array}$ & \\
\hline & $\begin{array}{l}\text { ?intu ka- } \\
\text { maSriyyi:n } \\
\text { إنتو اكصريين }\end{array}$ & 2 & $\begin{array}{l}\text { Interpersonal: } \\
\text { shows respect and } \\
\text { deference }\end{array}$ & \\
\hline & $\begin{array}{l}\text { naћnu } \\
\text { maSriyyi:n } \\
\text { نحن المصريين }\end{array}$ & 1 & $\begin{array}{l}\text { Interpersonal: } \\
\text { expresses intimacy } \\
\text { and solidarity }\end{array}$ & \\
\hline
\end{tabular}

Table 5 shows that the vocative il-maSriyyi: $n$ is utilized to maintain the interpersonal functions of respect and deference in two cases: first, when it is used alone (29 occurrences); and second, when it is preceded by the second person plural ?intu ( 2 occurrences). The same vocative expresses intimacy and solidarity when it is preceded

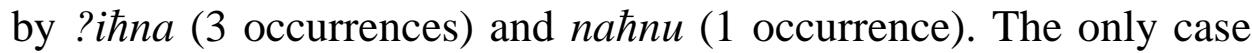
in which the vocative il-maSriyyi:n communicates a conversational

$$
\begin{aligned}
& \text { العدد الخامس والعشرون (الجزء الثاني) } 2019 \\
& \text { مجلة كلية الزبية- جامعة عين شمس165 }
\end{aligned}
$$


Do Directives Always Direct? Cognitive Directives and Meaning Inculcation in El-Sisi's Improvised Speeches

function is realized when it is preceded by the vocative particle $y a$, the equivalent of the English ' $\mathrm{O}$ ' (9 occurrences).

Seventh, and last, El-Sisi recurrently uses the Arabic mitigating

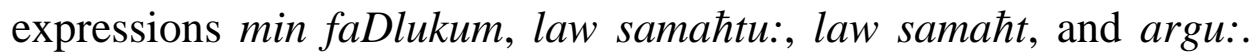
These are semantically equivalent to the mitigating please in English, and are often used before his directive commands to downgrade, in some cases, the force of the directive force. Despite the conventional use of please to indicate politeness on the part of the speaker, which aims to "mitigate the impositive speech act of requesting" (Martinez-Flor, 2009, p. 35), its Arabic equivalents have other functions that are used not only to soften the imposition carried out by the different types of directives, but also to seek a cooperative cognitive behavior on the part of the addressees. This can be displayed in the following table.

Table 6. Mitigators, their functions and frequency in El-Sisi's speech

\begin{tabular}{|c|c|c|c|c|}
\hline Mitigators & \multicolumn{2}{|c|}{ Frequency } & Pragmatic & Examples in context \\
\hline \multirow[t]{3}{*}{$\begin{array}{l}\text { min } \\
\text { faDlukum } \\
\text { من فضلكم }\end{array}$} & \multirow[t]{3}{*}{10} & 3 & $\begin{array}{l}\text { cognitive } \\
\text { behavior- } \\
\text { operator }\end{array}$ & $\begin{array}{l}\text { min faDlukum ?iftikru:ha } \\
\text { kuwayys }\end{array}$ \\
\hline & & 2 & $\begin{array}{l}\text { directive- } \\
\text { marker }\end{array}$ & $\begin{array}{l}\text { min faDlukum xallu: id- } \\
\text { dour mayb?a: } \text { li:h bu3d } \\
\text { siya:si }\end{array}$ \\
\hline & & 5 & attention-getter & $\begin{array}{l}\text { min faDlukum il-kla:m da } \\
\text { ?ana ba?u:luh li-kul in- } \\
\text { na:s }\end{array}$ \\
\hline \multirow[t]{2}{*}{ أرجو } & \multirow[t]{2}{*}{9} & 4 & $\begin{array}{l}\text { directive- } \\
\text { marker }\end{array}$ & $\begin{array}{l}\text { argu: ?in il-mawDu:3 da } \\
\text { manitkalim } \int i \text { fi:h tani }\end{array}$ \\
\hline & & 3 & $\begin{array}{l}\text { cognitive } \\
\text { behavior- } \\
\text { operator }\end{array}$ & $\begin{array}{l}\text { argu: ?in ?intu tantabihu } \\
\text { kuwayys ?awy li-dah }\end{array}$ \\
\hline
\end{tabular}

العدد الخامس والعشرون (الجزء الثانى)

مجلة كلية التربية- جامعة عين شمس166 
Ayman F. Khafaga

\begin{tabular}{|c|c|c|c|}
\hline & 2 & $\begin{array}{l}\text { request- } \\
\text { softener }\end{array}$ & $\begin{array}{l}\text { argu: ?in maћadif yaz3al } \\
\text { min kla:mi }\end{array}$ \\
\hline لو سمحت law samaht & 4 & attention-getter & $\begin{array}{l}\text { law samaht ?ana 3ayz } \\
\text { ?a?u:1 lil-maSriyyi:n } \\
\text { kilmah wahdah }\end{array}$ \\
\hline $\begin{array}{l}\text { law samaћtu: } \\
\text { لو سمحتو }\end{array}$ & 1 & $\begin{array}{l}\text { cognitive } \\
\text { behavior- } \\
\text { operator }\end{array}$ & $\begin{array}{l}\text { law samahtu: xallu: } \\
\text { il?umana:? waf-furafa:? } \\
\text { yataSadu hazihi: al- } \\
\text { ?intixaba:t }\end{array}$ \\
\hline
\end{tabular}

Table 6 clarifies that apart from their conventional use as politeness markers, El-Sisi uses the mitigating expressions as attention-getters (9 occurrences), cognitive behavior-operators (7 occurrences), directive-markers (6 occurrences), and request-softeners (2 occurrences). As shown in the above table, all mitigating expressions are contextualized within a command directive mood to assign a particular function that basically depends on the speaker's intention when he uses them. This, in turn, supports the concept of intentionality beyond meaning inculcation.

\section{Conclusion}

This paper investigated three types of directives in one of ElSisi's improvised speeches: directive questions, which are manifested in wh-questions, yes/no questions and alternative questions; directive commands, which are realized by letconstructions, attention getters and direct commands; and directive modality, which are represented by need statements and obligation modals. The analysis has evidenced the use of the three types of directives to inculcate certain presidential meanings that introduces El-Sisi as a successful, wise, diplomatic, powerful, fair, loyal, truthful, knowledgeable and far-sighted president. All these attributes revolve around one main theme: the presidential competency of El-Sisi (research question No.1).

One simple assumption is made in this paper: directives, under specific contextual circumstances, are not always used to direct the

$$
\begin{aligned}
& \text { العدد الخامس والعشرون (الجزء الثان) } 2019 \\
& \text { مجلة كلية الزبية- جامعة عين شمس } 167
\end{aligned}
$$




\section{Do Directives Always Direct? Cognitive Directives and Meaning}

Inculcation in EI-Sisi's Improvised Speeches

addressees, but they are intentionally employed to inculcate meanings by motivating a cognitive activity. This cognitive perspective allows this paper to propose what it calls 'cognitive directives': cognitive in the sense that they violate the force of pure directivity in seeking information (questions), prospecting a physical and/or verbal response (commands), or enforcing obligation (modality) towards a cognitive directivity that targets the inculcation of certain presidential meanings.

The analysis demonstrated that El-Sisi's directives, irrespective of their type, are employed to challenge the addresses' pragmatic competence. It is analytically evidenced that the three types of directives go beyond their semantically-based functions towards pragmatically-intended purposes. This is conducted by a dexterous process of meaning inculcation. These meanings have been contextually linked to the main semantic propositions constituting the whole speech by a skillful process of selection and combination to heighten El-Sisi's intended meanings. El-Sisi's directives, thus, can be said to go beyond the semantic towards the pragmatic (research question No. 2).

The analysis also showed that directive questions are more frequent than directive commands and directive modality. The question-and-answer discourse alleviates the illocutionary force of the interrogative mood and, thus, leaves no room for more interpretations to the utterance rather than what is cognitively understood from the immediately subsequent answers. The analysis further displayed a dexterous use of certain semantic and pragmatic devices, intentionally utilized within a directive mood, and discursively operate as meaning introducers and attention getters (frames and focus); markers of deference, intimacy, and discourse management(vocatives); and cognitive cooperation operators (mitigating expressions).

Finally, for future research, does a linguistic study to other two speeches of El-Sisi, one planned (written) and another improvised

العدد الخامس والعشرون (الجزء الثانى) 2019

()

مجلة كلية التربية- جامعة عين شمس 168 
like the one at hand, offer further linguistic evidences for an instruction-like presidential discourse? If so, does such a study reveal any differences between the discourse strategies used in each type of speeches to communicate specific presidential meanings on the semantic, pragmatic and/or stylistic levels of analysis? Does the application of the cognitive perspective of directives and ErvinTripp's (1976) classification of directives to other discourse genres, and in different discourse settings, explore how a parallel and reciprocal linguistic relativity can be captured between the different types of directives and these discourse genres? These are some issues that are worth fuller investigation and, therefore, they are awaiting further research. 


\section{Do Directives Always Direct? Cognitive Directives and Meaning}

Inculcation in EI-Sisi's Improvised Speeches

\section{References}

Abdel-Moety, D. (2015). A rhetorical and linguistic analysis of president El-Sisi's first inaugural address. Global Journal of HumanSocial Science: G Linguistics\& Education, 15(8), 1-12.

Austin, J. L. (1962). How to do things with words. Oxford: Oxford University Press.

Baicchi, A. (2015 ). Conceptual metaphor in the complex dynamics of illocutionary meaning. Review of Cognitive Linguistics, 13(1), 106-139.

Benz, A., \& Jasinskaja, K. (2017). Questions under discussion: From sentence to discourse. Discourse Processes, 54(3), 177-186. https://doi:10.1080/0163853X.2017.1316038

Blum-Kulka, S. (1987). Indirectness and politeness: Same or different. Journal of Pragmatics, 11 , 147-160.

Blum-Kulka, S. (1990). You don't touch lettuce with your fingers: Parental politeness in family discourse. Journal of pragmatics, 14(2), 259-288.

Brennenstuhl, W. (1987). Speech act sequences. In J. S. Petofi (Ed.), Text and discourse construction (pp. 54-69). Berlin: Walter de Gruyter.

Brinton, L. (1996). Pragmatic markers in English: Grammaticalization and discourse functions. Berlin: Mouton de Gruyter. https://doi.org/10.1515/9783110907582

Brown, P., \& Levinson, S. (1987). Politeness: Some universals in language usage. Cambridge: Cambridge University Press. https://doi.org/10.1017/CBO9780511813085

Clark, B. (1993). Relevance and pseudo-imperatives. Linguistics \& Philosophy, 16: 79-121. https://doi.org/10.1007/BF00984723

Clark, H. H. (2014). Spontaneous discourse. In M. Goldrick, V. S. Ferreira, \& M. Miozzo (Eds.), The Oxford handbook of

العدد الخامس والعشرون (الجزء الثالن) 2019

()

مجلة كلية التربية- جامعة عين شمس170 
language production (pp. 292-306). Oxford: Oxford University Press.

Condoravdi, C., \& Lauer, S. (2012). Imperatives: meaning and illocutionary force. In C. Piñon (Ed.), Empirical issues in syntax and semantics (Vol. 9, pp. 37-58). Papers from the Colloque de Syntaxe et Sémantique à Paris.

Crystal, D. (1992). An encyclopaedic dictionary of language and languages. Oxford: Blackwell.

Dascal, M. (2003). Interpretation and understanding. Amsterdam: John Benjamins.

Davies, E. (1986). The English imperative. London: Croom Helm.

Dontcheva-Navratilova, O. (2005). Politeness strategies in institutional speech acts. In R. Povolná, \& O. Dontcheva-Navratilova (Eds.), Discourse and Interaction 1. Brno Seminar on Linguistic Studies in English: Proceedings 2005 (pp. 15-29). Brno: Masaryk University.

Downes, W. (1977). The imperative and pragmatics. Journal of Linguistics, 13:

77-97. https://doi.org/10.1017/S0022226700005223

Dylgjeri, A. (2017). Analysis of speech acts in political speeches. European Journal of Social Sciences Studies, 2(2), 19-25.

El-Nawawy, M., \& Elmasry, M. (2016). The signs of a strongman: A semiotic and discourse analysis of Abdelfattah Al-Sisi's Egyptian presidential campaign. International Journal of Communication, 10, 2275-2296.

El-Sisi, A. (2016). Speech to the community representatives. Almenassa Media Center, available at (https://almanassa.com/ar/story/1505).

Ervin-Tripp, S. (1976). Is Sybil there? The structure of some American English directives. Language in Society, 5(1), 25-66. doi:10.1017/S0047404500006849

Fairclough, N. (2003). Analyzing discourse: Textual analysis for social research. London \&New York: Routledge.
العدد الخامس والعشرون (الجزء الثان) 2019
()

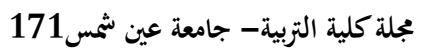




\section{Do Directives Always Direct? Cognitive Directives and Meaning}

\section{Inculcation in EI-Sisi's Improvised Speeches}

von Fintel, K. (2006). Modality and language. In D. M. Borchert (Ed.), Encyclopedia of philosophy (2 nd ed., Vol. 10, pp. 20-27). Detroit: MacMillan.

von Fintel, K., \& Iatridou, S. (2017). A modest proposal for the meaning of imperatives. In A. Arregui, M. L. Rivero, \& A. Salanova (Eds.), Modality across syntactic categories (pp. 288-319). Oxford University Press. https://doi.org/10.1093/acprof:oso/9780198718208.003.0013

García, F. G. (2000). Modulating grammar through modality: A discourse approach. ELIA, I, 119-136.

Gibson, J.J. (1979). The ecological approach to visual perception. Boston: Houghton Mifflin.

Goldschmidt, M. M. (1998). Do me a favor: A descriptive analysis of favor asking sequences in American English. Journal of Pragmatics, 29(2), 129-153.

Gordon, D., \& Lakoff, G. (1975). Conversational postulates. In P. Cole, \& J. L. Morgan (Eds.), Syntax and semantics: Speech acts (Vol. 3, pp. 83-106). New York: Academic Press.

Grice, H. (1975). Logic and conversation. In P. Cole, \& J. L. Morgan (Eds.), Syntax and semantic: Speech acts (Vol.3, pp. 41-58). New York: Academic Press.

Han, C. (2000). The structure and interpretation of imperatives: Mood and force in universal grammar. New York: Garland.

Huddleston, R. (1984). Introduction to the grammar of English. Cambridge: Cambridge University Press.

https://doi.org/10.1017/CBO9781139165785

Hussein, I. (2016). Critical discourse analysis of the political speech of the Egyptian president, Abdel Fattah El-Sisi, at the new Suez Canal inauguration ceremony. International Journal of Language and Literature, 4(1), 85-106.

Hyland, K. (2002). Directives: Arguments and engagement in academic writing. Applied Linguistics, 23(2), 215-239. https://doi.org/10.1093/applin/23.2.215

Jakobson, R. (1997). Linguistics and poetics. In K. M. Newton (Ed.), Twentieth-century literary theory: A reader (2 nd ed., pp. 7177). Macmillan Press LTD.

العدد الخامس والعشرون (الجزء الثان) 2019 
Kent, A., \& Kendrick, K. (2016). Imperative directives: Orientations to accountability. Research on Language and Social Interaction, 49(3), 272-288. https://doi.org/10.1080/08351813.2016.1201737

Leech, G. (1983). Principles of pragmatics. London: Longman.

Leech, G. (2014). The pragmatics of politeness. Oxford: Oxford University Press. https://doi.org/10.1093/acprof:oso/9780195341386.001.0001

Levelt, W. (1982). Linearization in describing spatial networks. In S. Peters, \& E. Saarinen, (Eds.), Processes, beliefs and questions (pp. 199-220). Dordrecht: Reidel.

Lyons, J. (1977). Semantics, Vol. 2. Cambridge: Cambridge University Press. https://doi.org/10.1017/CBO9780511620614.006

Lyons, J. (1981). Language and linguistics. Cambridge: Cambridge University Press. https://doi.org/10.1017/CBO9780511809859

Lyons, J. (1983). Deixis and modality. Sophia Linguistica, 12, 77-117.

Martinez, N. (2011). Cognitive modeling in illocutionary meaning. Review of Cognitive Linguistics, 9(2), 392-412.

Martinez-Flor. A. (2009). The use and function of "please" in learners' oral requestive behavior: A pragmatic analysis. Journal of English Studies, 7, 35-54. https://doi.org/10.18172/jes.140

Mbisike, R. (2008). Speech acts sequences in discourse. In S. G. Obeng, \& B. A. Hartford (Eds.), Political discourse analysis (pp. 6369). New York: Nova Science Publishers, Inc.

Naomi, G. (2018). Directives in Japanese workplace discourse. In H. M. Cook, \& J. S. Shibamoto-Smith (Eds.), Japanese at work. Communicating in professions and organizations (pp. 177-203).

Palgrave Macmillan, Cham. https://doi.org/10.1007/978-3-319$63549-1-8$

Norén, K., \& Linell, P. (2007). Meaning potentials and the interaction between lexis and contexts: An empirical substantiation. Pragmatics, 17(3), 387-416. https://doi.org/10.1075/prag.17.3.03nor

Palmer, F. R. (1986). Mood and modality. Cambridge: Cambridge University Press.
العدد الخامس والعشرون (الجزء الثان) 2019
()
مجلة كلية التربية- جامعة عين ثمس173 


\section{Do Directives Always Direct? Cognitive Directives and Meaning}

Inculcation in El-Sisi's Improvised Speeches

Portner, P. (2007). Imperatives and modals. Natural Language Semantics, 15, 351-383. https://doi.org/10.1007/s11050-007-9022-y

Povolná, R. (2018). On some persuasive strategies in technical discourse: Cross-cultural analysis of directives in English and Czech technical manuals. Topics in Linguistics, 19(2), 72-85. https://doi.org/10.2478/topling-2018-0011

Quirk, R., Greenbaum S., Leech, G., \& Svartvik, G. (1985). A comprehensive grammar of the English language. London: Longman.

Reddy, M. (1979). The conduit metaphor: A case of frame conflict in our language about language. In A. Ortony (Ed.), Metaphor and thought (pp. 248-324). Cambridge: Cambridge University Press.

Ross, A. (1968). Directives and norms. London: Routledge \& Kegan Paul.

Ryckebusch, C., \& Marcos, H. (2004). Speech acts, social context and parent-toddler play between the ages of $1 ; 5$ and 2; 3. Journal of Pragmatics, 36, 883-897. https://doi.org/10.1016/j.pragma.2003.10.019

Sadock, J. (1974). Toward a linguistic theory of speech acts. New York: Academic Press.

Safwat, S. (2015). Speech acts in political speeches. Journal of Modern Education Review, 5(7) 699-706.

Sager, J. C., Dungworth, D., \& McDonald, P. F. (1980). English special languages: Principles and practice in science and technology. Wiesbaden: Brandstetter.

Saito, J., \& Cook, H. M. (2018). Discourse in workplace discourse. In B. Vine (Ed.), The Routledge handbook of language in the workplace (pp. 203-215). New York \& London: Routledge.

Sameer, I. (2017). Analysis of speech act patterns in two Egyptian inaugural speeches. Studies in English Language and Education, 4(2), 134-147.

Searle, J. (1969). Speech acts. Cambridge: Cambridge University Press. https://doi.org/10.1017/CBO9781139173438

العدد الخامس والعشرون (الجزء الثانى)

()

مجلة كلية التربية- جامعة عين شمس174 
Searle, J. (1976). The classification of illocutionary acts. Language in Society, $5(1)$, $1-24$. https://doi.org/10.1017/S0047404500006837

Searle, J. (1979). Expression and meaning: Studies in the theory of speech acts. Cambridge: Cambridge University Press. https://doi.org/10.1017/CBO9780511609213

Sheveleva, A. (2012). Lingo-rhetorical and socio-pragmatic peculiarities in political speeches by Barack Obama. Intercultural Communication Studies, XXI(3), 53-62.

Simons, M., Tonhauser, J., Beaver, D., \& Roberts, C. (2010). What projects and why. In D. Lutz, \& N. Li (Eds.), Proceedings of SALT (Vol. 20, pp. 309-327). https://doi.org/10.3765/salt.v20i0.2584

Sinclair, J., \& Coulthard, M. (2002). Towards an analysis of discourse. In M. Coulthard (Ed.), Advances in spoken discourse analysis (pp. 1-34). London \& New York: Routledge.

Sindoni, G. M. (2013). Spoken and written discourse in online interactions: A multimodal approach. New York \& London: Routledge.

Sperber D., \& Wilson D. (1995). Relevance: Communication and cognition (2nd ed.). Oxford: Basil Blackwell.

Sudo, Y. (2007). Metalinguistic semantics for echo questions. In M. Aloni, P. Dekker, \& F. Roelofsen (Eds.), Proceedings of the sixteenth Amsterdam colloquium (pp. 205-210). Amsterdam: Palteam.

Taavistsainen, I. (1995). Interjections in early modern English: From imitation of spoken to conventions of written language. In $\mathrm{H}$. Jucker (Ed.), Historical pragmatics: Pragmatic developments in the history of English (pp. 439-468). Amsterdam: John Benjamins. https://doi.org/10.1075/pbns.35.23taa

Tapper, J. (1994). Directives used in college laboratory oral discourse. English for Specific Purposes, 13(3), 205-222. https://doi. 10.1016/0889-4906(94)90002-7
2019
العدد الحامس والعشرون (الجزء الثان)
()

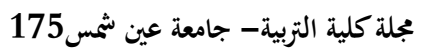




\section{Do Directives Always Direct? Cognitive Directives and Meaning}

Inculcation in El-Sisi's Improvised Speeches

Thornburg, L., \& Panther, K.-U. (1997). Speech act metonymies. In W. A. Liebert, G. Redeker, \& L. Waugh (Eds.), Discourse and perspective in cognitive linguistics (pp. 205-219). Amsterdam/ Philadelphia: John Benjamins.

Thorne, J. (1966). English imperative sentences. Journal of Linguistics, 2 , 69-78. https://doi.org/10.1017/S002222670000133X

Tsui, A. (2002). A functional description of questions. In M. Coulthard (Ed.), Advances in spoken discourse analysis (pp. 89-110). London \&New York: Routledge.

van Dijk, T.A. (1998). Cognitive context models and discourse. In M.

Stamenov (Ed.), Language structure, discourse and the access to consciousness (pp. 189-226). Amsterdam: Benjamins.

Vine, B. (2004). Getting things done at work: The discourse of power in workplace interaction (Vol. 124). John Benjamin.

Walton, A. (1991). Modality and the modals in traditional grammars of English. In G. Leitner (Ed.), English traditional grammars: An international perspective. Amsterdam: John Benjamin.

https://doi.org/10.1075/sihols.62.23wal

Wilson, D., \& Sperber, D. (1988). Mood and the analysis of nondeclarative sentences. In J. Dancy, J. Moravczik, \& C. Taylor (Eds.), Human agency: language, duty and value (pp. 277291). Stanford: Stanford University Press.

Yule, G. (1996). Pragmatics. Oxford University Press.

Zanuttini, R., \& Portner, P. (2003). Exclamative clauses: At the syntaxsemantics interface. Language, 79(1), 39-81. https://doi.org/10.1353/lan.2003.0105 transliterate 
Ayman F. Khafaga

\section{Appendix}

\section{List of the phonetic symbols used in the study and their description}

1. Consonants:

\begin{tabular}{l|l}
\hline Symbol & Phonetic description \\
\hline $\mathrm{b}$ & voiced bilabial stop \\
\hline $\mathrm{d}$ & voiced dental stop \\
\hline $\mathrm{D}$ & voiced (emphatic) dental stop \\
\hline $\mathrm{t}$ & voiceless dental stop \\
\hline $\mathrm{T}$ & voiceless (emphatic) dental stop \\
\hline $\mathrm{k}$ & voiceless velar stop \\
\hline $\mathrm{g}$ & voiced velar stop \\
\hline $\mathrm{q}$ & voiceless uvular stop \\
\hline f & voiceless glottal stop \\
\hline $\mathrm{f}$ & voiceless labiodental fricative \\
\hline $\mathrm{S}$ & voiceless dental fricative \\
\hline $\mathrm{S}$ & voiceless (emphatic) dental fricative \\
\hline $\mathrm{Z}$ & voiced dental fricative \\
\hline $\mathrm{S}$ & voiceless palatal fricative \\
\hline $\mathrm{h}$ & voiced pharyngeal fricative \\
\hline $\mathrm{h}$ & voiceless glottal fricative \\
\hline $\mathrm{x}$ & voiceless pharyngeal fricative \\
\hline $\mathrm{J}$ & voiceless uvular fricative \\
\hline $\mathrm{m}$ & voiced velar fricative \\
\hline $\mathrm{n}$ & voiced bilabial nasal \\
\hline $\mathrm{r}$ & voiced alveo-dental nasal \\
\hline $\mathrm{l}$ & voiced alveolar trill \\
\hline $\mathrm{y}$ & voiced alveolar lateral \\
\hline $\mathrm{W}$ & voiced palatal glide \\
\hline & voiced bilabial glide \\
\hline &
\end{tabular}


Do Directives Always Direct? Cognitive Directives and Meaning

Inculcation in El-Sisi's Improvised Speeches

\begin{tabular}{l|l}
\hline \hline \multicolumn{2}{c}{ 2. Vowels: } \\
\hline Symbol & Phonetic description \\
\hline $\mathrm{i}$ & close-front short unrounded vowel \\
\hline $\mathrm{i}:$ & close-front long unrounded vowel \\
\hline $\mathrm{a}$ & half-front open short unrounded vowel \\
\hline $\mathrm{a}:$ & $\begin{array}{l}\text { front-open long slightly rounded } \\
\text { vowel }\end{array}$ \\
\hline$\overline{\mathrm{a}}:$ & back-open long unrounded vowel \\
\hline $\mathrm{u}$ & half-close back short rounded vowel \\
\hline $\mathrm{u}:$ & close-back long rounded vowel \\
\hline $\mathrm{ei}$ & $\begin{array}{l}\text { open-mid front to close-high front } \\
\text { unrounded vowel }\end{array}$ \\
\hline
\end{tabular}

العدد الخامس والعشرون (الجزء الثانى) 2019 